\title{
Projection of Future Changes in Elephant Population in Amboseli under Representative Concentration Pathways
}

\author{
Mildred M. Aduma1 ${ }^{*}$, Mohamed Y. Said1 ${ }^{1}$, Gilbert Ouma1, Gordon Wayumba², Lucy W. Njino ${ }^{3}$ \\ ${ }^{1}$ University of Nairobi, Institute of Climate Change and Adaptation, Nairobi, Kenya \\ ${ }^{2}$ Technical University of Kenya, School of Surveying and Geospatial Sciences, Nairobi, Kenya \\ ${ }^{3}$ Directorate of Resource Surveys and Remote Sensing, Nairobi, Kenya \\ Email: *millyaduma@gmail.com, msaid362@gmail.com, gilbertouma@gmail.com, gowayumba@gmail.com, lnjino@gmail.com
}

How to cite this paper: Aduma, M.M., Said, M.Y., Ouma, G., Wayumba, G. and Njino, L.W. (2018) Projection of Future Changes in Elephant Population in Amboseli under Representative Concentration Pathways. American Journal of Climate Change, 7, 649-679.

https://doi.org/10.4236/ajcc.2018.74040

Received: October 2, 2018

Accepted: December 11, 2018

Published: December 14, 2018

Copyright $(9) 2018$ by authors and Scientific Research Publishing Inc. This work is licensed under the Creative Commons Attribution International License (CC BY 4.0).

http://creativecommons.org/licenses/by/4.0/

\begin{abstract}
Within savanna environments, movements of elephant are influenced by changes in climate especially seasonal rainfall. In this study, we investigated the possible changes in elephant population based on projected rainfall changes using regional climate models (RCM) and Representative Concentration Pathways (RCPs). The relationship between elephant and rainfall was modelled against annual, wet season, dry season rainfall based on various time lags. Future relation between elephant and rainfall was projected based on three RCPs; 2.6, 4.5 and 8.5. There was a strong linear relationship between elephant and October-November-December (OND) rains with time lag of 13 years $\left(\mathrm{Y}=-4016.43+19.11 \mathrm{x}, \mathrm{r}^{2}=0.459, \mathrm{P}=0.006\right)$. The rainfall trends for RCP 2.6 and 4.5 showed a slight increase in annual rainfall for the period 2006-2100 but driven by OND increases. Rainfall increase for RCP 8.5 was significant and was driven by increase in both March-April-May (MAM) and OND. These rainfall dynamics had influence on the projected elephant population in the Amboseli ecosystem. For RCP 2.6 and 4.5 the elephant population increase was 2455 and 2814 respectively. RCP 8.5 elephant population doubled to an average of 3348 elephants. In all the RCPs there are seasonal and yearly variations and absolute number varies from the average. The range of variation is small in RCPs 2.6 and 4.5 compared to RCP 8.5. Evidently, elephant population will increase based on projected rainfall projections surpassing park capacity. It therefore, requires that the Park authority put in place measures that could contain these numbers including opening of blocked wildlife corridors, maintain the cross border movement of Amboseli elephant with Tanzania in that case ensure there is no poaching. Lastly, work with local communities so that they can benefit from tourism through setting
\end{abstract}


up conservancies through which they could minimize the human elephant conflicts based on the projected elephant population.

\section{Keywords}

Representative Concentration Pathways 2.6, 4.5 and 8.5, Rainfall Variability, Population Dynamics

\section{Introduction}

Global land surface warming and increasing temperature events are expected to occur more frequently and more extremely causing changes in biodiversity and altering movement and survival of large herbivores [1]. There are increasing observations of escalating wildlife range losses worldwide. Climate change is predicted to have a major impact on plants and animals geographical distribution [2] [3] [4] [5]. Large wild terrestrial herbivore species are facing dramatic population declines and range contractions, and nearly $60 \%$ are already threatened with extinction [6]. The Intergovernmental Panel on Climate Change (IPCC) report of 2007 indicates that, for every $1^{\circ} \mathrm{C}$ rise in international mean temperature roughly $10 \%$ of species are likely to be exposed to disappearance risks [7].

The various ecosystems in the world are expected to experience varying stress from climate change impacts. Species responses include toleration, habitat shift or extinction, which are outcomes of exceeding species tolerance level of water and temperature stresses [8] [9]. Countless species are now being driven to change their geographic distributions and behavior as they respond to lifethreatening weather patterns that are associated with human induced climate change [3]. As they respond to change in climatic conditions, species tend to increase, decrease, or shift their range subject to their tolerance thresholds [3] [10]. Changes in seasonal natural life related events (phenology) such as plants flowering are also linked to climate change effects [8] [11]. These phenological changes affect migrant species which move around from one place to another in search for food, water and avoidance of poachers and predators. These species depend on environmental initiates like temperature, rainfall, and flowering to migrate [8] [11].

Africa is extremely susceptible to the impacts of climate change [12]. It is projected that temperatures in the region are likely to increase more rapidly than the other parts of the world, which might surpass $2^{\circ} \mathrm{C}$ by midway of the $21^{\text {st }}$ century and $4^{\circ} \mathrm{C}$ by the close of the $21^{\text {st }}$ century [12]. IPCC AR5 has indicated that future rainfall predictions are more indeterminate but expected to intensify in the eastern Africa and decrease in the southern part [12]. Warmer temperatures are expected to occur in the East African region with a 5\% - 20\% increase in rainfall from December-February and a 5\% - 10\% decrease in rainfall from June to August by 2050 [13]. The stated variations are likely not to be uniform throughout the year and are expected to occur erratically. It is anticipated that 
East African region will experience a reduction in the amount of precipitation received as a result of declines in long rains received during the March-April-May (MAM) season that has been linked to increased frequency of droughts in recent years [14] [15]. Past research has indicated that the amounts of rainfall in Kenya have been decreasing as from 1960 [16] [17] and future projections indicate that some portions of the country will suffer more than $100 \mathrm{~mm}$ of rainfall decline [18] while others might experience an increase in rainfall especially the October-November-December period [19].

While there is fairly inadequate evidence of current extinctions being caused by climate change, investigations insinuate that climate change could surpass habitat destruction as the greatest global threat to biodiversity over the next few decades [19]. Envisaging the reaction of biodiversity to climate change has become exceptionally important for the conservation of many species [9] [19] [20]. Predictive modelling plays a significant role in informing researchers and decision makers about impending upcoming threats, provide ways to augment attribution of biological changes to climate change and can sustain the development of practical approaches to lessen the impacts of climate change on biodiversity [2] [21]. Consequently, there is need to reexamine our current comprehension of the effects of climate change on biodiversity and our capacity to project future impacts using models. In this study we have focused on analyzing the impacts of projected climate change on the African elephant (Loxodonta africana).

Globally, the African elephant stands out as the largest mammal which was once widely distributed throughout Sub-Saharan Africa [22]. The species is currently sparsely distributed but still widespread in Africa [23]. Even though central and Western African populations have registered a drop, substantial populations still exist in Southern and eastern Africa. These latter populations continue to increase at a rate of approximately $4 \%$ per year [23]. The African elephant is categorized as "vulnerable" by the International Union for Conservation of Nature (IUCN). It is a water-dependent species with requirements of 150 to 300 litres of water per animal per day for drinking [24]. Acquisition of water forms a significant part of the daily activity for the species, although in wet seasons, elephants may go for three days without drinking [25]. Herds of elephants can walk considerable distances (30 to $50 \mathrm{~km}$ or more) in search of water [25]. They also respond quickly to changes in forage and water availability, making migrations in response to both large and small rainfall events [26]. Elephants are also well known for seasonal changes in their behaviour and are believed to change location in response to rain which they are hypothesized to sense through rain-system generated infrasound [27]. Elephants are also heat sensitive and individuals are susceptible to heat stress as well as sunburn. An increase in body temperature of 1 to $2^{\circ} \mathrm{C}$ is considered significant in its physiological undertaking [24].

In this study we investigated the possible changes in elephant population based on projected rainfall changes based on regional climate models (RCM). 
The simulations used for the projections are the Representative Concentration Pathways (RCPs), which are based on radiative forcings (globally radiative energy imbalance) measured in $\mathrm{Wm}^{-2}$ by the year 2100 [28]. The three RCPs used in this study are: RCPs 2.6, 4.5 and 8.5, which represent the low, mid and high-level emission and concentration scenarios, respectively.

\section{Study Area}

The Amboseli ecosystem is situated in the southwest of Kenya, bordering Tanzania. Geologically, the ecosystem covers part of a dry Pleistocene lake basin, which has a temporary lake that floods during years of heavy rainfall. Rainfall is bi-modal with short rains normally occurring in November and long rain period starts in March to May [29]. The area falls in the rain-shadow of Mt Kilimanjaro and receives between $300-500 \mathrm{~mm}$ of rain per year, placing it amongst the driest places in Kenya. However, water flowing underground from Mt Kilimanjaro wells up here a series of lush swamps that provide dry season water and forage for wildlife. This attracts high concentrations of migratory animals during the dry season.

The ecosystem covers an area of approximately $5700 \mathrm{~km}^{2}$ stretching between Chyulu Hills and Tsavo West National Parks South to Mt Kilimanjaro in Tanzania (Figure 1). Administratively, the Amboseli ecosystem consists of Amboseli National Park (ANP; $392 \mathrm{~km}^{2}$ ) and the six surrounding communally-owned Maasai group ranches and private lands that are important dispersal areas for wildlife. These group ranches and private lands cover an area of about $5063 \mathrm{~km}^{2}$ in Kajiado County (Figure 1). The tenure of the community owned land is changing rapidly to the detriment of the park and wildlife conservation in general. Olgulului-Ololorashi Group Ranches envelopes the park and they contain critical habitats and wildlife dispersal areas. It borders Eselenkei Group Ranch to the north which provides a wet season foraging area for the elephants while Ku$\mathrm{ku}$ and Mbirikani group ranches provide critical linkages to Chyulu and Tsavo West ecosystem respectively. Kimana group Ranch is to the southeast and Tanzania international border in the south. Olgulului-Ololorashi surrounds $90 \%$ of the Amboseli National Park and it covers an area of $1232 \mathrm{~km}^{2}$.

Rainfall in Amboseli ecosystem is bi-modal with long rain period being observed in March-April-May (MAM) and short rains in October-NovemberDecember (OND). The short dry seasons are January-February (JF) and long-dry season occurs in June-July-August-September (JJAS). The average annual rainfall for Amboseli ecosystem is $582 \mathrm{~mm}(\mathrm{SE}=25)$ with MAM contributing about average $228 \mathrm{~mm}(\mathrm{SE}=14)$, OND contributing $262 \mathrm{~mm}(\mathrm{SE}=18)$, JJAS contributing $20 \mathrm{~mm}(\mathrm{SE}=3)$ and JF $67 \mathrm{~mm}(\mathrm{SE}=9)$. The Amboseli ecosystem is one of the few areas in Kenya where the short rains are heavier than the long rains that take place between March and May in many parts of Kenya. The Amboseli ecosystem falls in the rain-shadow of Mt Kilimanjaro placing it amongst the driest places in Kenya. However, water flowing underground from Mt Kilimanjaro 


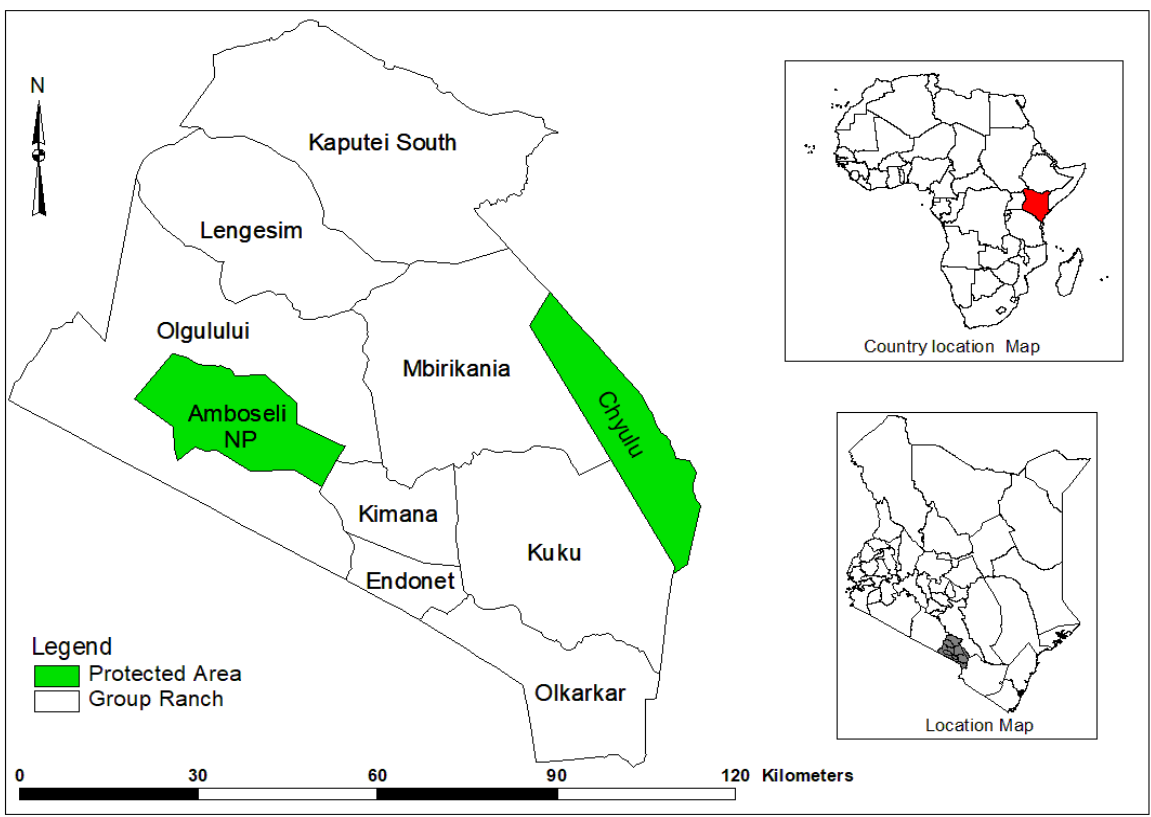

(a)

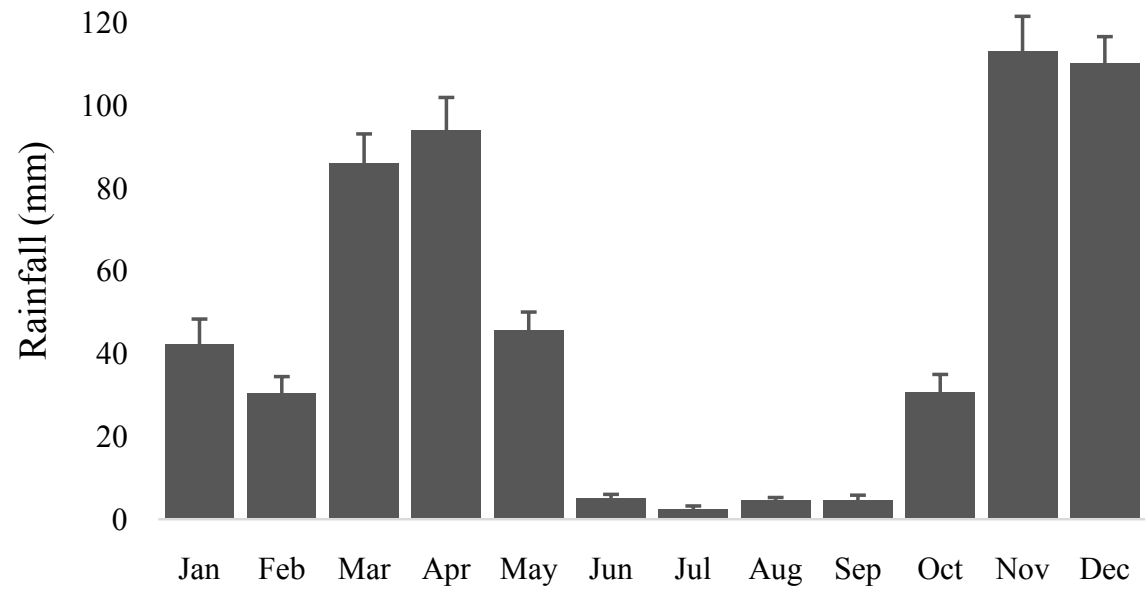

(b)

Figure 1. (a) Map showing location of study area the Amboseli Ecosystem; (b) Mean monthly rainfall with the standard errors for Amboseli ecosystem based on historical data from 1960 to 2014 .

wells up here in a series of lush swamps that provide dry season water and forage for wildlife. This attracts high concentrations of migratory animals during the dry season.

\section{Data}

\subsection{Aerial Surveys Count for the Elephant in the Amboseli Ecosystem}

In the present study we used elephant counts from 16 censuses conducted in the ecosystem between 1977 and 2014. Eight censuses were conducted in MarchApril-May (long rains), six in October-November-December (short rains) and 
two conducted in January-February (short dry season). The data was collected by the Directorate of Resource Surveys and Remote sensing (DRSRS) using a Systematic Reconnaissance Flight (SRF) [30]. High winged aircraft equipped with GPS, intercom, and radar altimeters are used for aerial census. A crew of a pilot, two rear seat observers (RSO) and one front seat observer (FSO) conduct the censuses. The RSO are responsible for animal counts, while the FSO assists in navigation, crew coordination and records general environmental parameters. The ecosystem was surveyed along transects in east-west direction and spaced at $5 \mathrm{~km}$ intervals. Topographic sheets of scale 1:250,000 are used for flight planning and all transects conformed to the Universal Transverse Mercator (UTM) projection system. Each transect was divided into equal sample sub units. During surveys a standard flying height and flying speed was maintained (see further details in [17]). A calibrated survey strip width was defined by rods mounted on the aircraft and by window markings. Only animals observed within the survey strip were recorded during the survey. During the survey all visual observations by RSO of animals within the survey strip were recorded using tape recorders. For herds greater than 10 animals, a photo was also taken. After every survey the tape-recorded observations were transcribed to data sheets. Photos were processed and interpreted for animal species. The census data were conducted.

\subsection{Historical Rainfall Data}

The rainfall and temperature data were extracted from the Geospatial Climate (GeoCLIM) software. GeoCLIM is a regional gridded climate data set tool that interpolates time-series grids of precipitation and temperature values from station observations and associated satellite imagery, elevation data, and other spatially continuous fields [31]. [32] has complied and validated the climate data for East Africa that was also used in the analysis of historical rainfall and temperature in the study site.

\subsection{Projected Climate Trends Based on Three RCPs 2.6, 4.5 and 8.5}

The IPCC (2013) [33] recommended a different series of scenarios known as Representative Concentration Pathways (RCPs) representing the full bandwidth of possible future emission trajectories. In this study, three Representative Concentration Pathways; $(2.6,4.5$, and 8.5$)$ were used. The first scenario (RCP 2.6) represents an optimistic projection characterized by a very low concentration and emissions levels of greenhouse gases, medium rate of population growth, the radiative forcing peaks at $3 \mathrm{Wm}^{-2}$ in 2050s before decreases in 2100 . The second scenario (RCP 4.5) is a scenario that stabilizes radiative forcing at $4.5 \mathrm{Wm}^{-2}$ in the year 2100 without ever exceeding that value. This scenario assumes that climate policies, in this instance the introduction of a set of global greenhouse gas emission prices, are invoked to achieve the goal of limiting emissions, concentrations and radiative forcing. The third scenario represents a pessimistic projection (RCP 8.5) with high levels of concentrations and emissions of greenhouse 
gases, a high rate of population growth and radiative forcing reaches $8.5 \mathrm{Wm}^{-2}$ by the end of the century, this scenario does not implement climate change policies [34] [35].

In this study we used the simulated data from the Ross by Center Regional Atmospheric Model (RCA4) driven by the Earth system version of the Max Planck Institute for Meteorology (MPI-ESM-LR) coupled global climate model from the on-going Coordinated Regional Downscaling Experiment (CORDEX) project. The goal of the RCM program is to advance the predictive understanding of Earth's climate by focusing on scientific analysis of the dominant sets of governing processes that describe climate change on regional scales. The model was integrated into the CORDEX-Africa domain, with a horizontal grid spacing of 0.44 degrees-translates to a 50 by $50 \mathrm{~km}$ grid (refer to [36] [37]). The historical simulations were forced by observed natural and anthropogenic atmospheric composition covering the period from 1950 until 2005, whereas the projections (2006-2100) were forced by Representative Concentration Pathways (RCPs).

\subsection{Statistical Analysis}

\subsubsection{Estimation of Elephant Population Size and Distribution}

The total animal population size, its variance and standard error are calculated using jolly's method 2 for aerial transects of unequal length [38]. The total population size is estimated as $\hat{Y}=Z \hat{R}$ with variance $\operatorname{Var}(\hat{Y})=\frac{N(N-n)}{n}\left(s_{y}^{2}-2 \hat{R} s_{z y}+\hat{R}^{2} s_{z}^{2}\right)$ and standard deviation $S E(\hat{Y})=\sqrt{ }(\operatorname{Var}(\hat{Y})) \cdot Z$ is the area of the census zone (e.g. county) and $\hat{R}=\frac{\sum y}{\sum z}$ is the sample population density calculated as the total number of all animals counted in each sampling unit $y$ divided by the area of each sampling unit $z$ summed over all the units included in the survey sample. $N$ is the population of all the sampling units in the census zone whereas $n$ is the number of sampling units included in the survey sample. $s_{y}^{2}$ is the sample variance of the number of animals counted in all the sampled units while $s_{z}^{2}$ is the variance of the area of all the sampling units included in the survey sample. $S_{z y}$ is the covariance between the number of animals counted and the area of each sampling unit.

We mapped elephant distribution based on aerial counts. The maps were based on grids cells of 5 by $5 \mathrm{~km}$. For any of the observed elephant we calculated its population in a grid and mapped those using ArcGIS.

\subsubsection{Analysis of Projected Rainfall for the Three RCPs 2.6, 4.5 and 8.5}

The monthly rainfall for all the three RCPs (2.6, 4.5 and 8.5) was analysed using linear and quadratic models for the period 2006-2100. The corrected Akaike Information Criterion (AICc) was used to choose between the supporting models. The model with the least AIC was selected as the supporting model [39]. 


\subsubsection{Statistical Models for Forecasting the Influence of Climate Change on Elephant Population}

We related annual elephant population elephant to rainfall components. The rainfall components defined as annual (October-September), short rains (October-December), long rains (March-May), long dry season (June-September), and short dry season (January-February) (see examples used in Lake Nakuru-[40]. The analysis was based moving averages ranging from one to 15 years. The corrected Akaike Information Criterion (AICc) was used to choose between the supporting models [39]. We also tested if temperature had an effect on the elephant population.

\subsubsection{Testing the Elephant Population Differences between the RCPs}

We tested the differences between projected elephant population between RCPs: 2.5, 4.5 and 8.5 based on two-sample t-test. The null hypothesis tends that there is no difference between the two RCPs elephant population or more formally, that the difference is zero. Formally expressed as $\mathrm{H} 0: \mathrm{p} 1-\mathrm{p} 2=0$, where $\mathrm{p} 1$ is the first population and $\mathrm{p} 2$ is the second population.

\section{Results}

\subsection{Elephant Population Trend in Amboseli Ecosystem}

Figure 2 shows the trends of the elephant population in the Amboseli for the period 1977-2014. There was significant increase in the elephant population between 1977 and $2014\left(\mathrm{r}^{2}=0.44, \mathrm{~F}=10.02\right.$ and $\mathrm{P}=0.007$; refer to Figure 2). The elephant population in Amboseli ecosystem has increased from about 480 elephants in 1977-78 to 1400 elephants in 2011-2013. The elephant population in Amboseli ecosystem has increased by about $300 \%$ or at a growth rate of $2.4 \%$ per year.

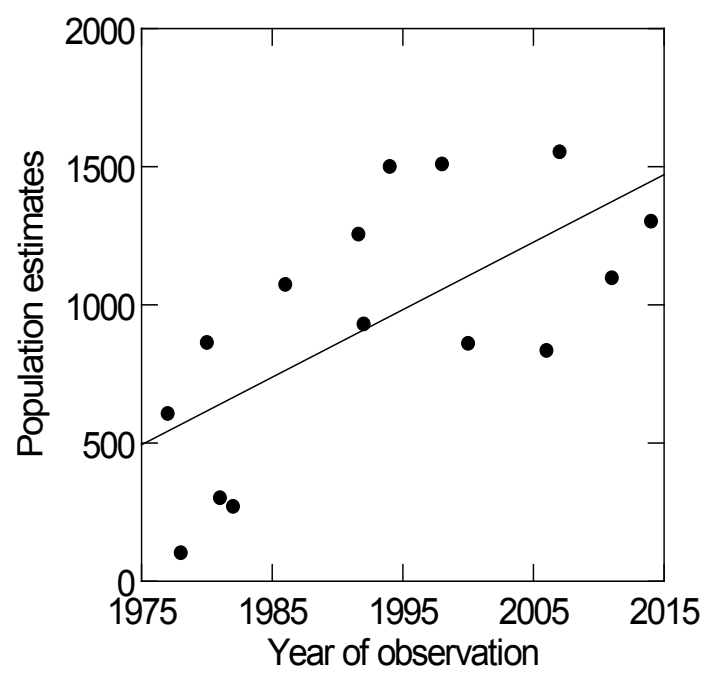

Figure 2. Elephant population trend in the Amboseli Ecosystem between 1977 and 2014 showing an increasing population. 


\subsection{Distribution of Elephant in the Amboseli Ecosystem 1977-2014}

In this study we mapped the distribution of elephants between 1977 and 2014. The elephant in Amboseli ecosystem disperse with the onset of rains, but there was little indication of evidence of large scale elephant migration in Amboseli. It is reported that in Amboseli the elephant seasonal range is influenced to some extent by the intensity of poaching, rainfall and the development of artificial water resources within the park and surrounding areas. In the last 2 decades the elephant population has increased and also they are moving out of the park more often.

Our analysis indicates two patterns of elephant distribution in the Amboseli ecosystem. These two patterns indicate that the elephant can be confined to the park or at times move out. Most of the elephants were confined to the park in the 1970s and to late 1980s. The confinement of elephants was mainly because of the heavy poaching in the 1970s and early 1980s. However after 1991 we have observed large dispersal of elephant beyond the park and especially between the periods 2000 to 2014 . The total elephant range increased significantly and with many elephants sighted in the park and in adjacent group ranches of Lengesim, Imbirikani, Kuku Olgulului and Kimana (refer to Figure 3 and Figure 1(a)).

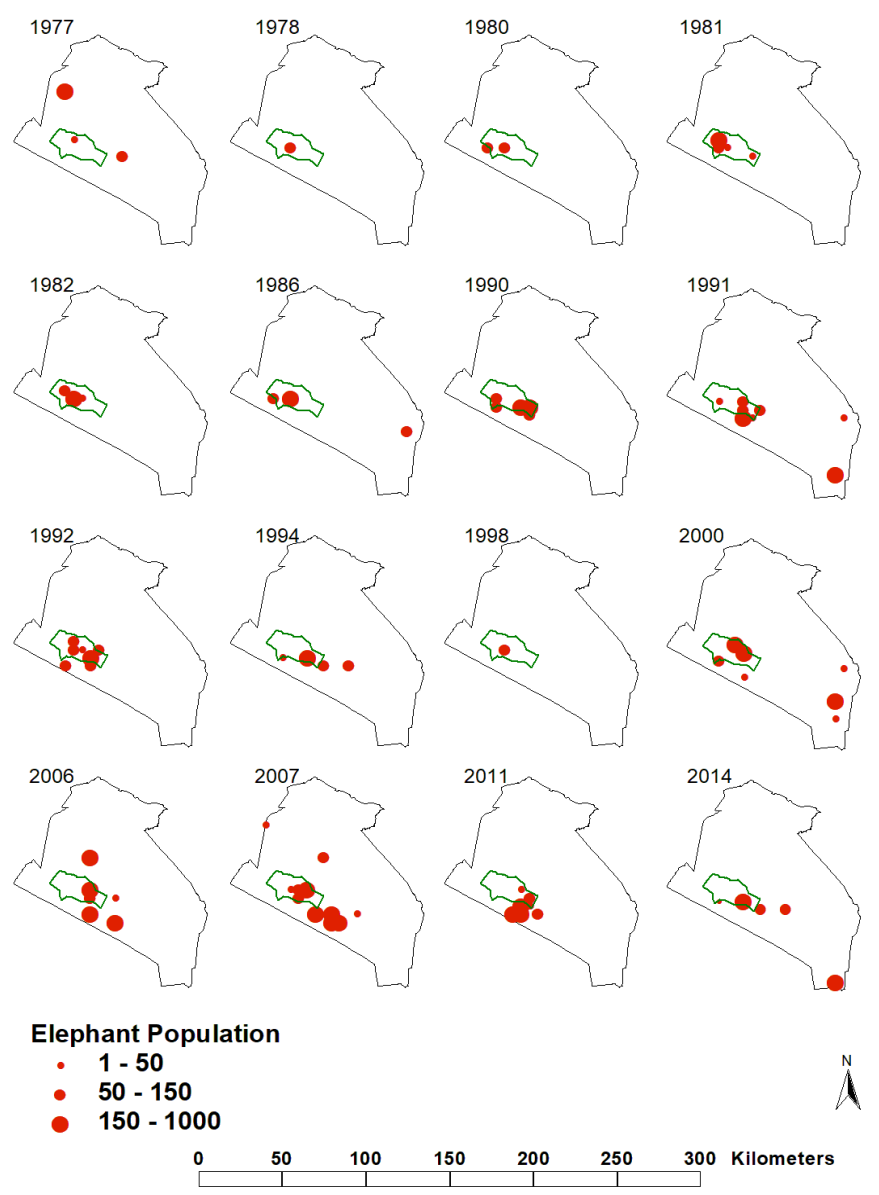

Figure 3. Distribution of elephant in the Amboseli ecosystem 1977-2014. 


\subsection{Historical Rainfall Trends}

The historical trends of monthly rainfall in the Amboseli ecosystem shows slight increases rainfall in March, August and December, slight decline in rainfall in January, February, April, May, September, October and November (Figure 4 and Table S1). However, there was significant decline of rainfall in the long dry season for the months of June $(\mathrm{Y}=244.544-0.212 \mathrm{x} ; \mathrm{F}=3.979, \mathrm{P}=0.051)$ and July $(\mathrm{Y}=254.688-0.127 \mathrm{x} ; \mathrm{F}=5.672, \mathrm{P}=0.021)$.

\subsection{Relationship between Elephant Population with Temperature and Rainfall}

The relationship between elephant population and temperature were not significant as tested with moving average from one to twelve months (refer to Table S3). We therefore opted out further analysis of elephant with rainfall the relationship between elephant and rainfall was modelled with annual, MAM, OND, ONDJF and JJAS rainfall and based on various time lags. The MAM, ONDJF and JJAS all indicate weak and insignificant relationship between elephant population and rainfall. However, the OND and annual rainfall season showed a strong relationship with elephant population (refer to Table 1). The OND rainfall moving average of 13 years lag showed a strong positive relationship between elephant population and rainfall (see Table $1 ; \mathrm{r}^{2}=0.459, \mathrm{~F}=11.01, \mathrm{P}=0.006$; Figure 5). The annual rainfall moving average of 15 years showed a strong negative relationship between elephant population and rainfall (see Table $1 ; \mathrm{r}^{2}=$ $0.616, \mathrm{~F}=20.56, \mathrm{P}=0.001$ ).

\subsection{Projected Rainfall for Amboseli Ecosystem for the Three Scenarios RCP 2.6, RCP 4.5 and RCP 8.5}

The projected seasonal rainfall in Amboseli ecosystem varies across RCPs 2.6, 4.5 and 8.5. Table 2(a)-(c) summarizes annual, MAM, JJAS and OND seasonal rainfall for the three RCPs. The RCPs 2.6 indicate a decline in rainfall for the all the four seasons though not significant (refer to Table 2(a)). The mean annual rainfall is $632 \mathrm{~mm}$ with most rainfall occurring in OND with a mean rainfall of $313 \mathrm{~mm}$ compared to MAM mean rainfall of $211 \mathrm{~mm}$. The driest season is JJAS with an average of $34 \mathrm{~mm}$ and having the highest coefficient of variation of $64 \%$. OND has the least coefficient of variation of $31 \%$.

RCP 4.5 annual rainfall is projected to increase marginally and is mainly driven by increases in rainfall for the OND season (Table 2(b) and Figure 6(e) and Figure $6(\mathrm{~h})$ ). It is projected that MAM and JJAS will decline slightly (Figure 6(f) and Figure 6(g)). The mean annual rainfall for RCP 4.5 is $692 \mathrm{~mm}$, for OND is $340 \mathrm{~mm}$, for MAM is $261 \mathrm{~mm}$ and for JJAS is $33 \mathrm{~mm}$. It is projected for OND the maximum rainfall will reach $757 \mathrm{~mm}$ and minimum will be $158 \mathrm{~mm}$. MAM maximum rainfall is projected to $561 \mathrm{~mm}$ and minimum of $61 \mathrm{~mm}$. There is a large variation between OND and MAM with OND having more rainfall and less coefficient of variation of rainfall of $29 \%$ compared to MAM where the coefficient of variation is projected at $39 \%$. 
a) January

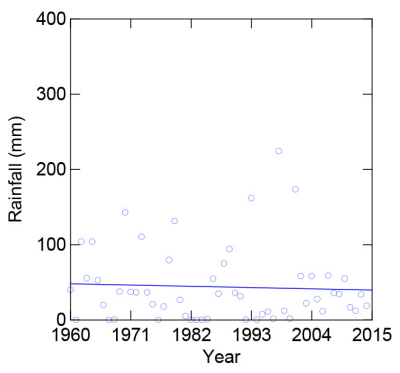

a) May

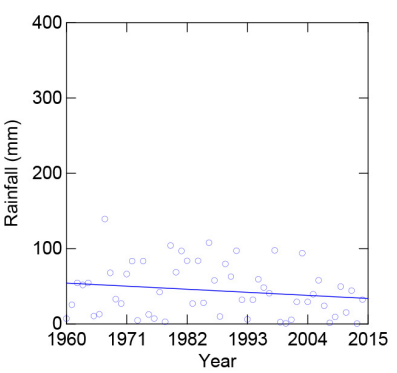

a) September

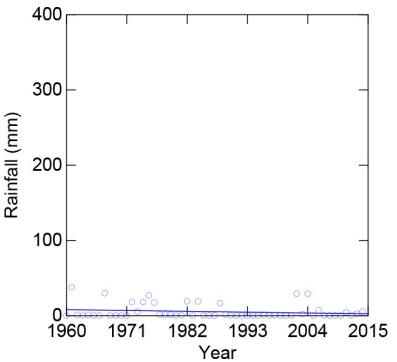

a) February

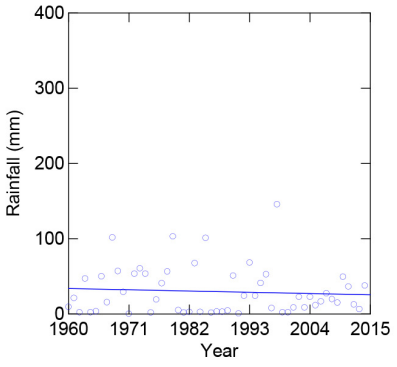

a) June

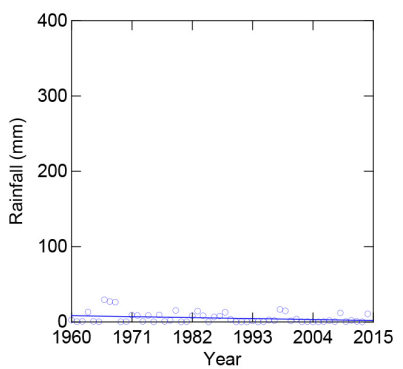

a) October

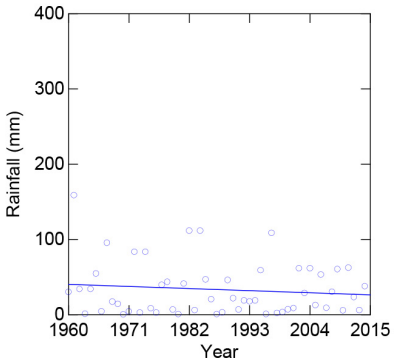

a) March

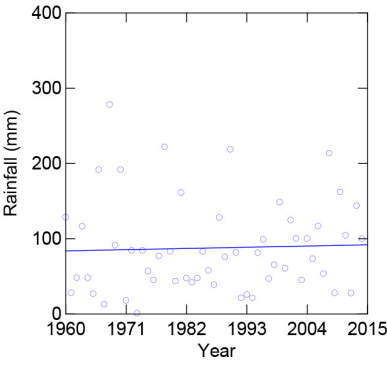

a) July

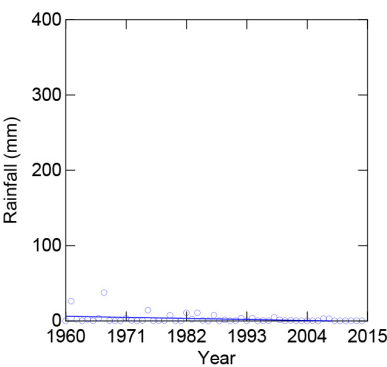

a) November

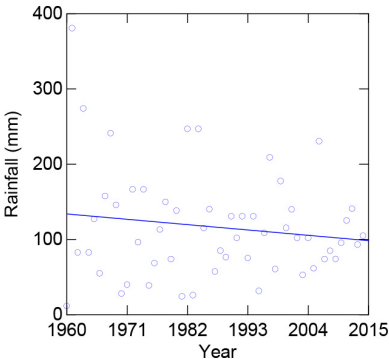

a) April

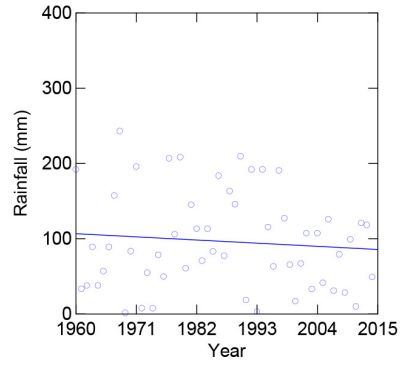

a) August

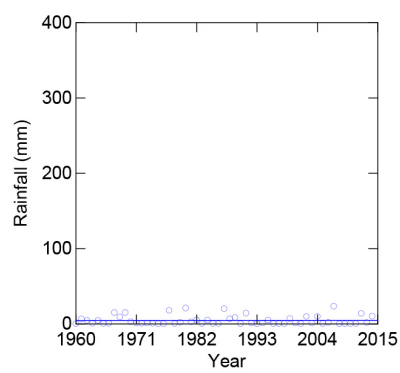

a) December

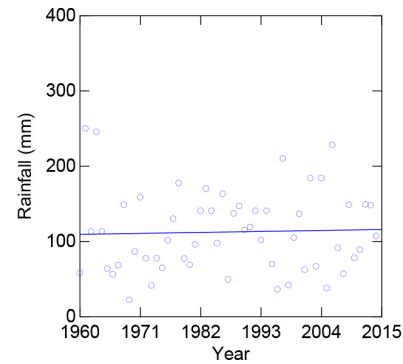

Figure 4. Monthly rainfall trends in the Amboseli-ecosystem between 1960 and 2014.

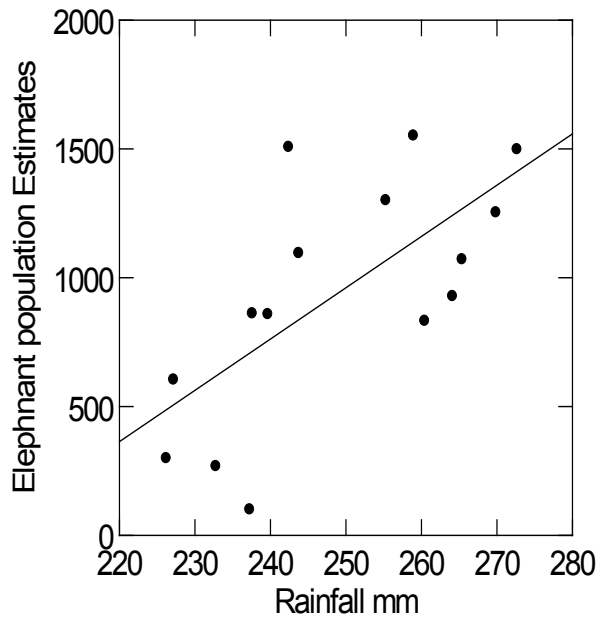

Figure 5. The relationships between elephant and the best supported cumulative moving averages $\left(\mathrm{OND}_{13}\right)$. 
Table 1. Statistics describing relationships between the population of elephant and preceding rainfall over 8 - 15 year in Amboseli Ecosystem.

\begin{tabular}{ccccccc}
\hline $\begin{array}{c}\text { Rainfall } \\
\text { component }\end{array}$ & Constant & Slope & SE & F-ratio & P value & r-squared \\
\hline $\mathrm{OND}_{8}$ & -1428.83 & 9.4658 & 4.7722 & 3.93 & 0.069 & 0.232 \\
$\mathrm{OND}_{10}$ & -1874.40 & 10.977 & 5.172 & 4.50 & 0.054 & 0.257 \\
$\mathrm{OND}_{12}$ & -2757.43 & 14.744 & 5.107 & 8.33 & 0.012 & 0.390 \\
$\mathrm{OND}_{13}$ & -4016.43 & 19.911 & 6.001 & 11.01 & 0.006 & 0.459 \\
$\mathrm{OND}_{14}$ & -4476.79 & 21.325 & 6.881 & 9.61 & 0.008 & 0.425 \\
$\mathrm{OND}_{15}$ & -3509.13 & 17.558 & 8.934 & 3.86 & 0.071 & 0.229 \\
Annual $_{12}$ & 6082.95 & -7.774 & 3.569 & 4.74 & 0.048 & 0.267 \\
Annual $_{13}$ & 6588.23 & -8.519 & 3.824 & 4.96 & 0.044 & 0.276 \\
Annual $_{14}$ & 7528.14 & -9.875 & 3.009 & 10.77 & 0.006 & 0.453 \\
Annual $_{15}$ & 8425.17 & -11.233 & 2.460 & 20.56 & 0.001 & 0.616 \\
\hline
\end{tabular}

Table 2. (a) Seasonal rainfall trend for Amboseli Ecosystem for RCP 2.6; (b) Seasonal rainfall trend for Amboseli Ecosystem for RCP 4.5; (c) Seasonal rainfall trend for Amboseli Ecosystem for RCP 8.5.

(a)

\begin{tabular}{cccc}
\hline Month & Equation & F-Ratio & P-Value \\
\hline Annual & $\mathrm{Y}=763.587-0.0640 \mathrm{x}$ & 0.0154 & 0.9014 \\
MAM & $\mathrm{Y}=346.714-0.0615 \mathrm{x}$ & 0.0434 & 0.8354 \\
JJAS & $\mathrm{Y}=94.4536-0.0295 \mathrm{x}$ & 0.1308 & 0.7183 \\
OND & $\mathrm{Y}=485.237-0.0799 \mathrm{x}$ & 0.0445 & 0.8333 \\
\hline
\end{tabular}

(b)

\begin{tabular}{cccc}
\hline Month & Equation & F-Ratio & P-Value \\
\hline Annual & $\mathrm{Y}=287.983+0.1968 \mathrm{x}$ & 0.0990 & 0.7536 \\
MAM & $\mathrm{Y}=465.295-0.0996 \mathrm{x}$ & 0.0681 & 0.7946 \\
JJAS & $\mathrm{Y}=81.2521-0.0236 \mathrm{x}$ & 0.1082 & 0.7428 \\
OND & $\mathrm{Y}=-25.1041+0.2879 \mathrm{x}$ & 0.6140 & 0.4352 \\
\hline
\end{tabular}

(c)

\begin{tabular}{cccc}
\hline Month & Equation & F-Ratio & P-Value \\
\hline Annual & $\mathrm{Y}=-400.653+2.3022 \mathrm{x}$ & 15.2661 & 0.0002 \\
MAM & $\mathrm{Y}=-344.632+0.2937 \mathrm{x}$ & 0.7950 & 0.3748 \\
JJAS & $\mathrm{Y}=390.734-0.1767 \mathrm{x}$ & 6.4588 & 0.0126 \\
OND & $\mathrm{Y}=-3017.99+1.6509 \mathrm{x}$ & 17.251 & 0.0001 \\
\hline
\end{tabular}

Amongst the three RCPs the RCP 8.5 is projected will have an increase in rainfall significantly for the period 2006-2100 $(\mathrm{P}=0.0002$; refer Table $2(\mathrm{c}))$. The increase in annual is contributed by both the MAM and OND. The increase in OND is highly significant $(\mathrm{P}=0.0001$, refer to Table $2(\mathrm{c})$ ). The mean annual rainfall for RCP 8.5 is projected at $720 \mathrm{~mm}$. The variation between the maximum $(1267 \mathrm{~mm})$ and minimum $(388 \mathrm{~mm})$ is the highest amongst the three 
(a) RCP 2.6 - Annual

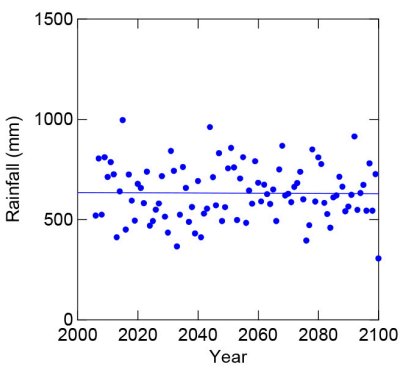

(e) RCP 4.5 - Annual

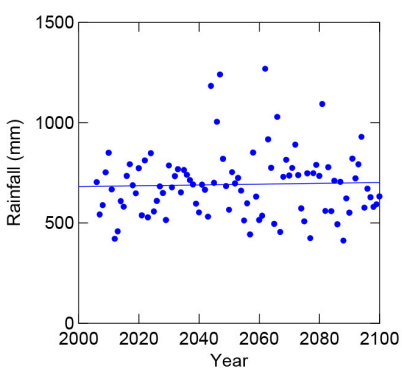

(i) RCP 8.5 - Annual

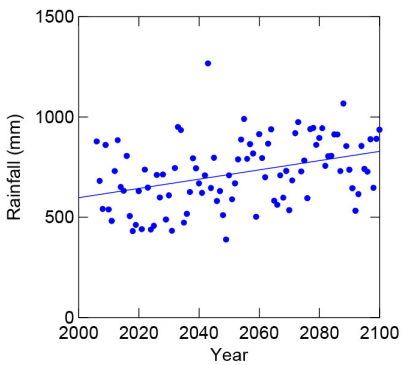

(b) RCP 2.6 - MAM

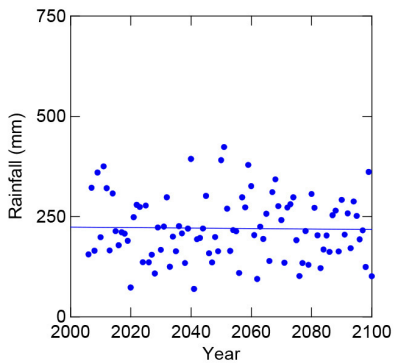

(f) RCP 4.5 - MAM

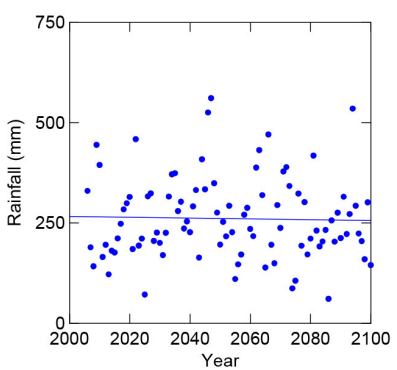

(j) RCP 8.5 - MAM

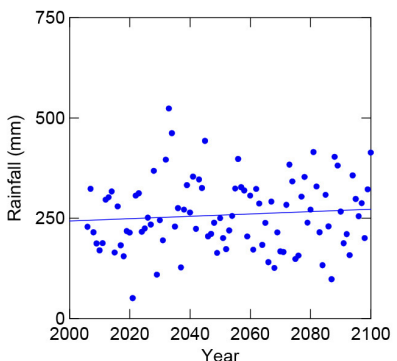

(c) RCP 2.6 - JJAS

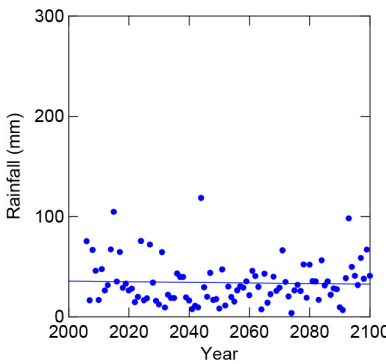

(g) RCP 4.5 - JJAS

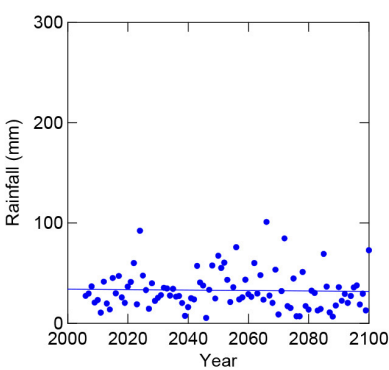

(k) RCP 8.5 - JJAS

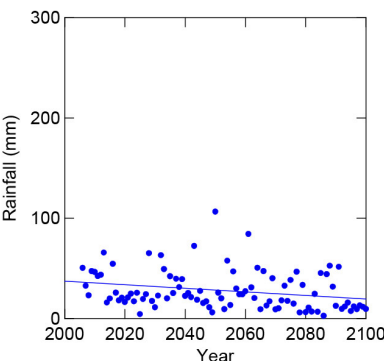

(d) RCP 2.6 - OND

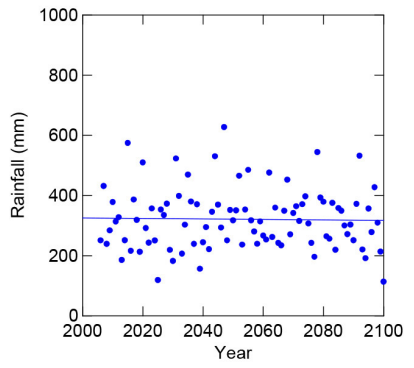

(h) RCP 4.5 - OND

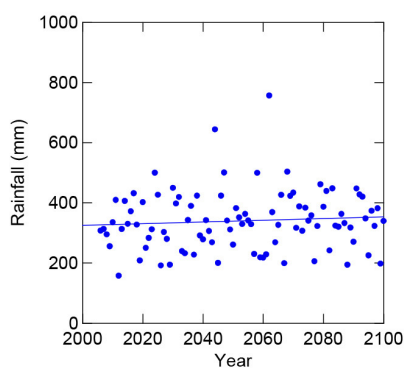

(I) RCP 8.5 - OND

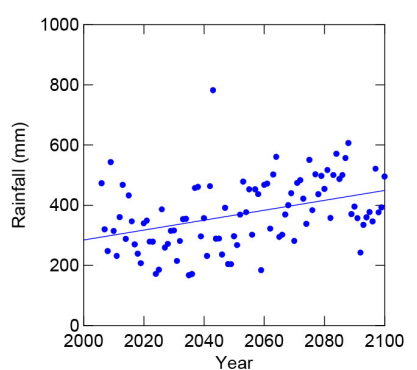

Figure 6. Projected seasonal rainfall for Amboseli ecosystem for RCP 2.6, 4.5 and 8.5 for the period 2006-2100.

RCPs. The OND maximum rainfall is projected at $782 \mathrm{~mm}$ and minimum 167 mm while the maximum in MAM is $523 \mathrm{~mm}$ and minimum is $51 \mathrm{~mm}$ (Figure 6(i) and Figure 6(j)). The RCP 8.5 JJAS season has the highest coefficient of variation of $69 \%$ the maximum projected rainfall is set at $107 \mathrm{~mm}$ and minimum at $3 \mathrm{~mm}$ (Figure $6(\mathrm{k})$ ). The projected rainfall trend for JJAS is it will significantly decline $(\mathrm{P}=0.0126$; Table $2(\mathrm{c}))$ and become drier. In RCP 8.5 indicates occurrence of extremes of both wet and dry weather in the Amboseli ecosystem.

\subsection{Projected Elephant Population in Amboseli Ecosystem for the Three RCPs 2.6, 4.5 and 8.5}

The three RCPs project an increase in elephant population in the Amboseli Ecosystem (Figure 7(a)). There is a high correlation of elephant projections between RCP 2.6 and RCP 4.5. The projected average elephant population in Amboseli for RCP 2.6 for the period 2019-2040 is 2200 elephant. Between 2040 and 2070 the elephant population will increase to a maximum of 3510 animals by 

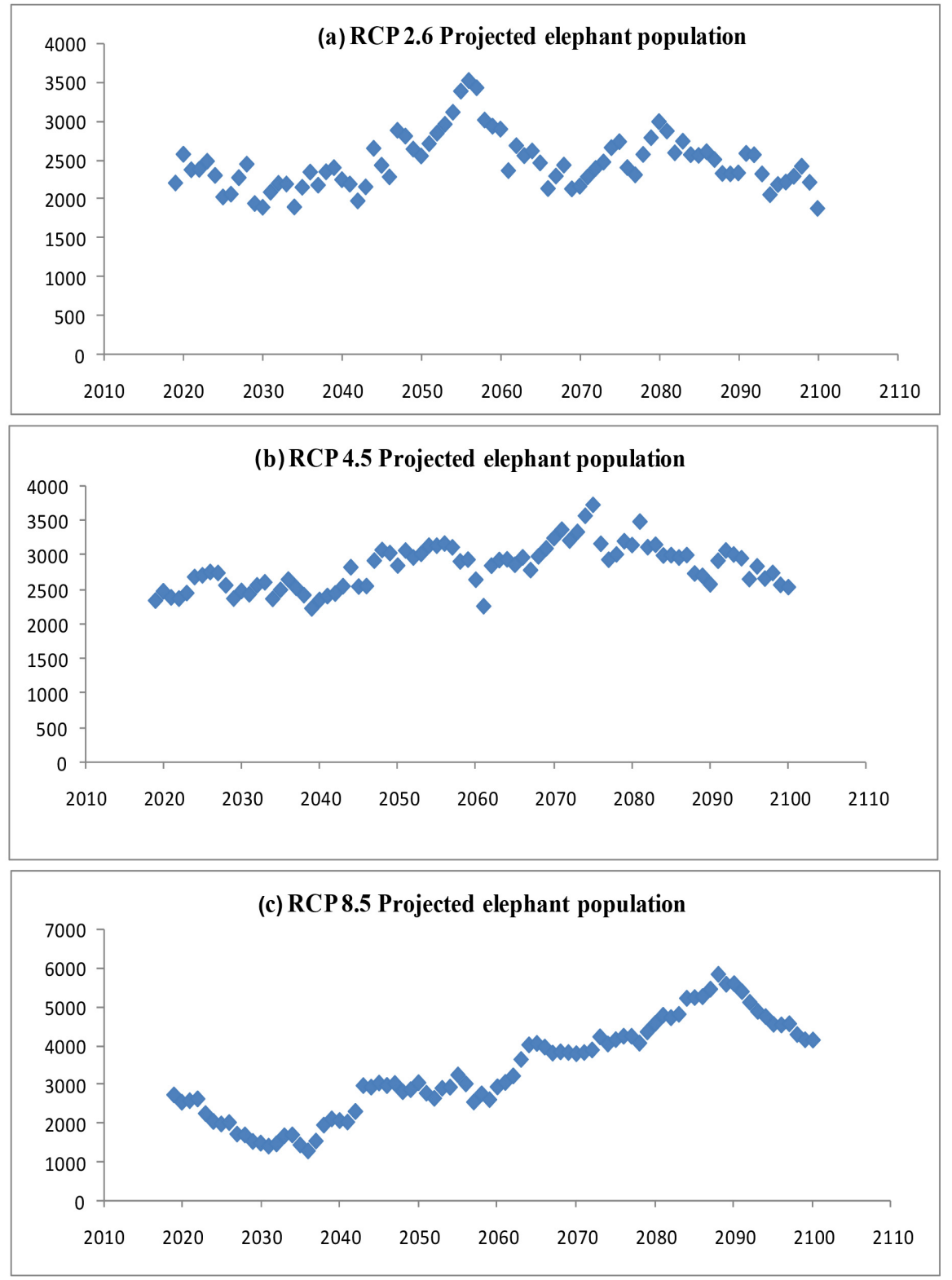

Figure 7. Projected elephant population of the three RCPs 2.5, 4.5 and 8.5based on OND rainfall.

2056 after this decline to about 2160 elephants by 2070 . There will be another phase of increase of elephants and by 2080 it is projected there will be 2980 elephant but after this period it will decline to about 1870 animals by 2100 (Figure $7(a))$.

The trend for RCP 4.5 shows three phases-the first phase is between 2019 and 2050 where the projected population of elephants is likely to increase from 2300 to 3020 elephants by 2050 (Figure 7(b)). The second phase the elephant population will stabilize at 2930 animals between year 2051 and 2069. Thereafter, the population will increase to a maximum of 3725 elephants in 2075. In the third phase it is projected the population will decline to 1870 elephant by year 
2100 (refer Figure 7(b)).

As indicated in the analysis of rainfall that RCP 8.5 both the annual and OND is projected will increase significantly. The population of elephant is mirrored to the rainfall pattern. The population of elephant under RCP 4.5 has seven different trends or broken stick (Figure 7(c)). The projected elephant under RCP 8.5 for the period 2019 to 2036 indicate elephants will decline from a population of 2715 in 2019 to 1270 animals in 2036. In the second phase it is projected the elephants will increase to maximum of 2950 animals in 2043. Between 2043 and 2060 the elephant numbers will be on average about 2870 animals and these will increase to 4000 elephants by 2064 . Between 2064 and 2078 the average elephant population will be 3890 and this will increase to the maximum of 5820 elephants in 2088. After this period it is projected the elephants will decline to a population of about 4130 by 2100 (Figure $7(\mathrm{c})$ ).

Table 3 summarizes the projected elephant population in the Amboseli ecosystem for RCPs 2.5, 4.5 and 8.5. The RCP 2.6 has the lowest mean population of 2457 (SD 340) elephants and RCP 8.5 has the highest mean of 3349 (SD 1226). The sample t-test between projected elephant population for RCP 2.6 and 4.5 shows significant difference in mean population (Pooled Variance $\mathrm{t}=$ $-6.910040, \mathrm{df}=162$, Prob $=0.000000$; Figure 8) with highest population for RCP 2.6 projected to be realized in year 2056 and for RCP 4.5 in 2075. There was significant and higher variations in projected mean elephant population between RCP 2.6 and RCP 8.5 (Pooled Variance $\mathrm{t}=-6.339137, \mathrm{df}=162$, Prob $=$ 0.000000; Figure 8) and RCP 4.5 and RCP 8.5 (Pooled Variance $t=-3.812024$, $\mathrm{df}=162$, Prob $=0.000196$; Figure 8 ). RCP 8.5 has the largest projected elephant population amongst the three RCPs. Its maximum number is projected at 5820 elephants and minimum is at 1272 elephants.

\section{Discussion}

It is broadly recognized that, within savanna environments, movements of elephant are influenced by changes in seasonal rainfall [4] [41] [42]. Communities that have lived for centuries in close contact with elephants have myths and legends that explain the relationship between elephants and rainfall. Samburu people of Central Kenya believe that the sighting of an elephant after months of no rain signals the coming of the rains [43]. Elephants alter their movement activities both in response to a seasonal changes in rainfall (dry to wet) and to wet episodes occurring in the dry season. The responses are triggered by rainfall occurring at some distant location, perhaps as much as $300 \mathrm{~km}$ from the location of the elephants [44] [45] examining elephant movement patterns in conjunction with rainfall patterns indicated that all herds under observation changed their behavior at two distinct thresholds: at the end of the dry season before the first rains commenced, and at the end of the wet season, during the period of the highest average daily rainfall. Such a conditioning may well play a significant role in changing the general movement behavior of the current elephant population 
Table 3. Summary of projected elephant population in the Amboseli ecosystem for three RCPs between the years 2019 to 2100 .

\begin{tabular}{ccccccc}
\hline & & \multicolumn{3}{c}{ Maximum elephant population } & \multicolumn{2}{c}{ Minimum elephant population } \\
\hline RCP & Mean & N & Year & Number & Year & Number \\
2.6 & $2457($ SD 340) & 82 & 2056 & 3510 & 2100 & 1870 \\
4.5 & $2815($ SD 322) & 82 & 2075 & 3725 & 2039 & 2216 \\
8.5 & $3349($ SD 1226) & 82 & 2088 & 5820 & 2036 & 1272 \\
\hline
\end{tabular}
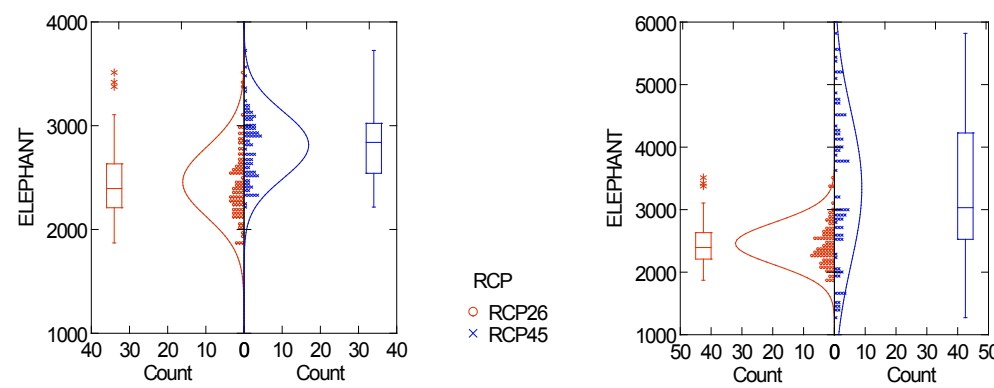

$\mathrm{RCP}$

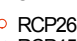

RCP26
$\times$ RCP45

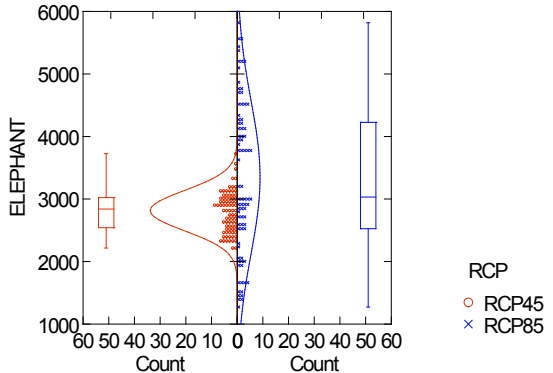

Figure 8. Frequency and boxplot showing the differences in the mean, minimum and maximum elephant population projected for RCPs; 2.5, 4.5 and 8.5 between the year 2019 and 2100.

in Amboseli ecosystem as indicated in the distribution elephants between 1977 and 2014. The distribution was mainly governed by rainfall season and security. In the 1970s, 1980s and early 1990s the elephant were mostly found in the park and later years the elephant moved more often outside the park because of better protection [92] [99].

Therefore, in this paper we focused on analysing the relationships between elephant population and rainfall and temperature in the Amboseli ecosystem. Analysis of historical rainfall data of the study area from 1960-2014 showed a bimodal pattern of rainfall with two rainy seasons and two dry seasons [1]. The year in Amboseli ecosystem begins in October and ends the following September and is linked closely to the annual cycle of growth of vegetation in the study site [46]. It is also evident in Amboseli ecosystem that the shorter rainfall season of October-November-December (OND) receives more rainfall compared to the long-rains of March-May season (MAM). This is one of the few ecosystems in Kenya where the OND receives more rainfall than MAM.

In this study our analysis has established a strong positive relationship between 
elephant population and OND season with a lag of 13 years. Previous studies in the savannah ecosystem such as in the Tsavo [47] Mara [48] [49] Lake Nakuru [50], Amboseli [51] in Kenya, Serengeti in Tanzania [52], and Addo National Park in South Africa [53] have established the population of ungulates varied with rainfall and were driven by annuals, season (wet or dry) or a combination of seasons and that there could be also be lags [50]. However, the time lags were shorter than 10 years. In the savannah the elephant is one of the key wildlife species that has a long-life span. Elephants have a life span of about 60 years and are not reproductive before they are 10 years old [54]. The median age at first reproduction in elephants is approximately 13 years [55]. Research has shown that animals with longer life spans respond more slowly to changes in the environment [56]. The variability of rainfall and the time lag of response are such that populations never reach a stationary age distribution [56].

Other drivers of changes to elephant population are extreme events such as droughts and high rainfall as experienced during the El Niño and increasing temperatures. A number of studies have also shown a positive or negative correlation between extreme events such as El Niño or droughts and elephant population. In Addo National Park the highest elephant population growth rate coincided with El Niño rains [53]. Similarly the high rate of increase elephant population witnessed in Samburu National Reserve occurred during the "El Nino" rains of 1997 that produced the highest rainfall in the region since 1961 [57]. On the contrary the highest mortality witnessed in the same Samburu National Reserve occurred during severe drought of 2008-2009 droughts [58]. In this study the relationship between elephant and maximum temperature show a positive linear relationship for a period of one to twelve months but none was significant.

A study on potential impacts of projected temperature based on RCP 2.5, 4.5 and 8.5 changes on the elephant range showed minimal impacts on elephant whilst for other large herbivore the impacts on their range will significant [1] It is estimated that there were once more than 350 species of elephants in the world [59] Today we only have two living species of elephant, namely; The African elephant (Loxodonta africana) and the Asiatic elephant (Elephas maximus). Five subspecies are recognized, two belonging to the African elephant and three belonging to the Asiatic elephant. The African bush elephant differs from other elephants mainly due to its adaptations geared towards living in hot, arid environments. They have the largest ears of all elephants, helping to keep the animal cool under the hot sun. It is the only elephant that is primarily a grazer, and as such possesses molars with large cusps that assist in chewing tough grasses, bark and twigs that are found throughout its habitat [59] Sweat glands help lower the animal's body temperature on a hot day and they appear to be highly specialized in African bush elephants.

Therefore, in the study we focused on analysing the potential projected impacts of rainfall on the elephant population in the Amboseli ecosystem. It is important to project the potential changes of climate on both animals and plants. There have been efforts to project rainfall and temperatures based on Global 
Circulation Models (GCMs) in the last six decades [60] [61]. Although GCMs can satisfactorily simulate the atmospheric general circulation at the global or continental scales, they are not necessarily capable of capturing the detailed processes associated with regional-local climate variability and changes [62] [63]. One broadly used method for achieving high resolution climate information that takes into account regional patterns and valuable local knowledge is to use regional climate models (RCMs) [64]. In this study we used Regional Climate Model (RCM) simulated data from the Rossby Center regional Atmospheric model (RCA4) driven by the Earth system version of the Max Planck Institute for Meteorology (MPI-ESM-LR) coupled global climate model from the on-going Coordinated Regional Downscaling Experiment (CORDEX) project. A recent assessment study by [37] showed that the RCA model run driven by MPI-ESM-LR better reproduces the large-scale signals such as the El Niño Southern Oscillation (ENSO) and the Indian Ocean Dipole (IOD) in the historical period over the Eastern Africa region than RCA model run driven by the other GCMs. A deep-rooted agreement by the climate change science society is that the downscaling of the raw output of climate change experiments from the Global Climate Model (GCM) is necessary for impact applications at regional to local scale [65] [66] [67] [68] [69]. These RCMs are improved framework for generating regional-scale climate projections for impact assessment and adaptation studies worldwide within the IPCC AR5 timeline and beyond.

The three climate models selected for this study had variations in projections for rainfall between 2006 and 2100 for Amboseli ecosystem. Projections for RCP 2.6 indicate an overall decline in rainfall driven by projected declines of rainfall in MAM, JJAS and OND. RCP 4.5 predicts that there will be overall marginal increase in annual rainfall which is driven by increase in OND. The mean annual rainfall for RCP 4.5 is $692 \mathrm{~mm}$, for OND is $340 \mathrm{~mm}$, for MAM is $261 \mathrm{~mm}$ and for JJAS is $33 \mathrm{~mm}$. Projections for RCP 8.5 indicate a statistically significant increase in annual rainfall which is mainly driven by significant projected increase in OND rainfall. The OND maximum rainfall is projected at $782 \mathrm{~mm}$ and minimum $167 \mathrm{~mm}$ while the maximum in MAM is $523 \mathrm{~mm}$ and minimum is 51 $\mathrm{mm}$. [70] indicated too that the high emission scenario which is RCP 8.5 projects an increase in the total amount of annual precipitation with at least $1 \mathrm{~mm}$ of precipitation in tropical eastern Africa. In contrast to global models, regional climate model projects no change, or even a drying for East Africa, especially during long rains [71] It is evident from our study that there will be mostly likely be decreases in the MAM long rains for RCP 2.6 and 4.5. On the contrary it projected there will be increases in OND for RCP 4.5 and 8.5. The increases in rainfall with extremes for both RCP 4.5 and 8.5 might be driven by temperatures changes which are projected to increase between $3^{\circ} \mathrm{C}$ to $5^{\circ} \mathrm{C}$ in African savannas [72].

Increase in intensity of extreme precipitation events has been found to be related to increases in temperatures [73]. Climate models project that most regions in the world will experience continuous increase in precipitation extremes in the 
21st century [74] [75] [76]. Both global and regional models driven with future scenarios of increasing $\mathrm{CO}_{2}$ concentrations produce an increase of precipitation intensity and extremes as warming continues in the future [74] [75] [76]. Climate models project both the peak of extreme precipitation and the temperature at which it peaks will increase with warming; the two increases generally conform to the Clausius-Clapeyron (C-C) relationship scaling rate in mid- and high-latitudes, and to a super $\mathrm{C}-\mathrm{C}$ scaling in most of the tropics [77]. The changes in rainfall for the three RCPs will have different effects on the elephant population.

Since the rainfall pattern for RCP 2.6 and RCP 4.5 were almost similar the elephant population projection and pattern are much similar. RCP 2.6 projects an average elephant population at 2457 with a peak population being realized in 2056 at a population density of 3510 elephants while RCP 4.5 projects an average population density of 2815 elephants in the long term with the highest population being realized in 2075 at 3725 elephants) and lowest population is projected by 2100 at a population density of 1870 elephants. The population of elephant under RCP 8.5 reveals a different trend; initially the population is expected to drop from a population of 2715 elephants to 1270 elephants by 2036 then an increase to a maximum of 5820 elephants by 2088. After this period it is projected the elephants will decline to a population of about 4130 by 2100 . In between 2045 and 2060 the average population is projected around 2966 elephants and another stable state of population will be between 2065 and 2080 where is projected the elephant average population will be 4039 elephants. Recent study by [78] using mathematical models demonstrate that the elephant population of Amboseli National Park (ANP) between 2008 and 2032 will experience a significant exponential growth. Based on ARIMA model the population would increase from 1451 elephants in 2008 to 2514 elephants by 2032 which is close to what we have predicted under RCP 2.6 and RCP 4.5 .

In terms of breeding and genetics a change in the intensity or duration of the rainy versus drought seasons could change relative breeding rates and, hence, genetic structures in these populations [79] [80] have documented that breeding in African elephants (Loxodonta africana) occurs all year-round, however the dominant males mate during the wet season while subordinate males breed in the dry season. It has been documented that during dry periods elephants experience high juvenile elephant mortality [46] [81] [82] [83]. The male calves born in dry years have reduced life expectancy and reduced body sizes [84]. Adult elephants are also affected by severe drought which leads to increased mortality [83] [85] [86]. On the contrary studies have shown that elephants have highest survival rates during the wettest months. A study by [87] on Asian elephant indicated more survival of the elephants for all ages sexes when the year is dominated by wet season. The same has been observed with the African elephants where mortality decreases significantly in the wet season [46] [84]. Therefore increased rains in the OND season will have a positive impact on the elephant 
population of Amboseli ecosystem but work on elephant population dynamics is needed (refer to [49] [88]

As indicated in this study that it is projected there is likely possibilities of increase in elephant population based on all the three RCPs 2.6, 4.5 and 8.5 in the Amboseli ecosystem which could boost tourism activities in the area. However, sustainability of the population in the limited park space will be a big challenge because the Amboseli Park alone will not be able to sustain the numbers and therefore most elephants will have to move into the dispersal areas outside the park. It is therefore likely that there will be an increase in human elephant conflicts as the human population in rangelands is expected to continue increasing in the coming years [89]. The population of Kajiado has increased from 149,005 in 1979 to 687,312 people in 2009 [90] [91]. And this is projected to increase to 1.4 million people by 2030 at a growth rate of $3.4 \%$ and 2.8 million people by 2050. Although elephants may be resilient to climate change because they are long ranging [1] [92] other drivers like habitat loss and fragmentation are known to cause a decline in their population [93] [94].

In addition encroachment on elephant habitats that is blocking migration routes [95] [96] will continue to be exacerbated by the impacts of climate change that is making the area hotter and drier affecting availability of key natural resources to both elephants and people [92]. These threats to elephants are likely to continue in the future and will threaten the gains made in Amboseli to reduce elephant mortality and increase viable populations since national parks and reserves are currently facing challenges to sustain populations of large mammals and opportunities for expanding existing parks and reserves are diminishing [97]. Sustainability of large elephant populations in a fragmented and patchy ecosystem will require extraordinary conservation measures. It will be extremely important to invest in effectively conserving wildlife and their habitats in the privately or communally owned pastoral rangelands [98]. Further, success in dealing with the projected increase in elephant population lies in policies that integrate national, private and community conservation initiatives. Such policies are likely to succeed in maintaining wildlife populations at ecosystem, landscape and regional scales.

In most savanna ecosystems land fragmentation is recognized to be a major threat to wildlife distribution [94] [99]. The Amboseli ecosystem is becoming patchy as a result of unregulated expansion of settlements and agriculture which encroach into the rangelands [94] coupled with urban centers and infrastructural development. The land use in Amboseli ecosystem is changing rapidly from predominantly pastoralism to agro-pastoralism and agriculture thereby increasing the farming community [92]. In Amboseli ecosystem $61 \%$ of the land has been privatised, $28 \%$ is still under group ranch tenure and $11 \%$ is protected (Amboseli National Park and Chuylu; Said et al., 2018).

Further, lack of direct benefits from wildlife based-tourism has prompted the local people to shift to horticultural farming and leasing of farms to commercial farmers [100]. The group ranches are experiencing a growing human population 
with increasing subsistence demands that have led to an 543 increase in land subdivision [101]. These demands have resulted in changes in land tenure from group to individual ownership, consequently resulting in land resources in the ecosystem being divided between pastoralism, conservation and agriculture. If RCP 8.5 elephant population takes place (doubling the current population) increased conflicts will be witnessed with the surrounding community, hence other measures might need to take place such as trans-locating elephants to different locations.

The projected elephant population based on the three RCPs indicates moderate increases in elephant for RCP 2.6 and RCP 4.5 and high increase for RCP 8.5. On average the elephant population for RCP 2.6 is projected at 2457 while for RCP 4.5 is about 2815 elephant and RCP 8.5 are at 3349 elephants. The projected increase can be managed through engaging the local communities, since elephants disperse to the community and private lands and their survival depends on the goodwill of the local community. This implies that any conservation action should have a human socio-economic dimension and not only focus on elephant welfare, but that of the local community who bear the cost of elephant conservation.

Population predictions or projections based on time series models, linear models, deterministic or stochastic structured models and simulations play an important role in population management [102]. Projection of future populations, given a management strategy is fundamental to population management. It is also mandatory to know the essential threshold of the population's key factors that are affected by a management strategy, if we wish to conserve a population successfully [103]. Application of management plans must be centered on the specific population that we desire to conserve, or else the population may become extinct due to arbitrary application of management policies. Scientifically verifiable methods of population conservation are thus encouraged.

\section{Conclusion}

As indicated in the rainfall analysis, for RCP 8.5, both the annual and OND are projected to increase significantly. The population of elephant is mirrored to the rainfall pattern. Research analysis established a strong positive relationship between elephant population and OND season with a lag of 13 years. Elephant is one of the key wildlife species that has a long life span and this study projects an increase in elephant population based on all the three RCPs 2.6, 4.5 and 8.5 in the Amboseli ecosystem. The increase could boost tourism activities in the area. However, sustainability of the population in the limited park space will be a big challenge because the Amboseli Park alone will not be able to sustain the numbers and therefore most elephants will have to move into the dispersal areas outside the park. It is therefore likely that there will be an increase in human elephant conflicts as the human population in rangelands is expected to continue increasing in the coming years. Therefore, there is need to have national and county policies that will allow translocation of animals to other locations to ease 
the pressure on the diminishing resources. The County of Kajiado should also come up with a strategic plan that focuses on encouraging local community not to shift to crop cultivation in entirety, instead support the community to come together and form conservancies where the main land use is wildlife conservation so as to secure the wildlife corridors. This can be enhanced by Economic incentives to communities that promote wildlife conservation as an important resolution to encourage involvement of local communities in biodiversity conservation efforts. Finally, there is need to enhance the trans-boundary agreement and control of poaching between Kenya and Tanzania for the population to grow and benefit the tourism sectors of both counties.

\section{Acknowledgements}

The authors gratefully acknowledge funding support provided through the $\mathrm{Na}$ tional commission for Science, Technology and Innovation (NACOSTI) under the Research Endowment Fund $6^{\text {th }}$ call postgraduate 2014/2015 grants. The authors also wish to thank anonymous reviewers for their suggestions, which resulted in the improvement of the manuscript. We thank the Directorate of Resource Surveys and Remote Sensing of Kenya (DRSRS) for permission to use the aerial survey data. We are grateful to Hussen Seid and Herbert Misiani of ICPAC for providing the projected rainfall data. Mohamed Said was supported by the Pathways to Resilience in Semi-Arid Economies (PRISE) Project 5-Property regimes, investments and economic development in the context of climate change in semi-arid lands of East Africa.

\section{Data availability}

The datasets generated during and/or analyzed during the current study are available from the corresponding author on reasonable request.

\section{Conflicts of Interest}

The authors declare that they have no conflict of interest regarding publication of this article.

\section{References}

[1] Aduma, M.M., Ouma, G., Said, M.Y., et al. (2018) Potential Impacts of Temperature Projections on Selected Large Herbivores in Savanna Ecosystem of Kenya. American Journal of Climate Change, 7, 5-26. https://doi.org/10.4236/ajcc.2018.71003

[2] Parmesan, C., Burrows, M.T., Duarte, C.M., et al. (2013) Beyond Climate Change Attribution in Conservation and Ecological Research. Ecology Letters, 16, 58-71. https://doi.org/10.1111/ele.12098

[3] Monzón, J., Moyer-Horner, L. and Palamar, M.B. (2011) Climate Change and Species Range Dynamics in Protected Areas. Bioscience, 61, 752-761. https://doi.org/10.1525/bio.2011.61.10.5

[4] Young, K.D., Ferreira, S.M. and Van Aarde, R.J. (2009) Elephant Spatial Use in Wet and Dry Savannas of Southern Africa. Journal of Zoology, 278, 189-205. 
https://doi.org/10.1111/j.1469-7998.2009.00568.x

[5] Ceballos, G., Ehrlich, P.R. and Dirzo, R. (2017) Biological Annihilation via the Ongoing Sixth Mass Extinction Signaled by Vertebrate Population Losses and Declines. Proceedings of the National Academy of Sciences of the United States of America, 114, E6089-E6096. https://doi.org/10.1073/pnas.1704949114

[6] Ripple, W.J., Newsome, T.M., Wolf, C., et al. (2015) Collapse of the World's Largest Herbivores. Science Advances, 1, e1400103. https://doi.org/10.1126/sciadv.1400103

[7] IPCC 2007 (2007) Summary for Policymakers. In: Solomon, S., Qin, D., Manning, M., Chen, Z., Marquis, M. and Ave, K.B., Eds., Climate Change 2007: The Physical Science Basis. Contribution of Working Group I to the Fourth Assessment Report of the Intergovernmental Panel on Climate Change Cambridge, United Kingdom and New York, NY, USA.

[8] Cahill, A.E., Aiello-Lammens, M.E., Fisher-Reid, M.C., et al. (2012) How Does Climate Change Cause Extinction? Proceedings of the Royal Society B: Biological Sciences, 280, 20121890. https://doi.org/10.1098/rspb.2012.1890

[9] Dawson, T.P., Jackson, S.T., House, J.I., et al. (2011) Beyond Predictions: Biodiversity Conservation in a Changing Climate. Science, 332, 53-58.

https://doi.org/10.1126/science.1200303

[10] Parmesan, C. (2006) Ecological and Evolutionary Responses to Recent Climate Change. Annual Review of Ecology, Evolution, and Systematics, 37, 637-669.

[11] Dunlop, M. and Brown, P. (2008) Implications of Climate Change for Australia's National Reserve System: A Preliminary Assessment.

https://www.environment.gov.au/system/files/resources/917bb661-b626-44bb-bd52 -325645ae7c49/files/nrs-report.pdf

[12] Niang, I., Ruppel, O.C., Abdrabo, M.A., Essel, A., Lennard, C., Padgham, J. and Urquhart, P. (2014) Africa. In: Climate Change 2014: Impacts, Adaptation, and Vulnerability. Part B: Regional Aspects. Contribution of Working Group II to the Fifth Assessment Report of the Intergovernmental Panel on Climate Change, Cambridge University Press, Cambridge, UK, 1199-1265.

[13] Hulme, M., Doherty, R., Ngara, T., New, M. and Lister, D. (2001) African Climate Change: 1900-2100. Climate Research, 17, 145-168. https://doi.org/10.3354/cr017145

[14] FEWS NET (2011) East Africa: Past Year One of the Driest on Record in the Eastern Horn. Famine Early Warning System Network Rep.

[15] Lyon, B. and Dewitt, D.G. (2012) A Recent and Abrupt Decline in the East African Long Rains. Geophysical Research Letters, 39, 1-5. https://doi.org/10.1029/2011GL050337

[16] Cooper, P.J.M. and Coe, R. (2011) Assessing and Addressing Climate-Induced Risk in Sub-Saharan Rainfed Agriculture. Experimental Agriculture, 47, 179-184. https://doi.org/10.1017/S0014479711000019

[17] Ogutu, J.O., Piepho, H., Said, M.Y., et al. (2016) Extreme Wildlife Declines and Concurrent Increase in Livestock Numbers in Kenya: What Are the Causes? PLoS ONE, 11, e0163249.

[18] Endris, H.S., Lennard, C., Hewitson, B., et al. (2016) Teleconnection Responses in Multi-GCM Driven CORDEX RCMs over Eastern Africa. Climate Dynamics, 46, 2821-2846. https://doi.org/10.1007/s00382-015-2734-7

[19] Leadley, P., Pereira, H., Alkemade, R., et al. (2010) Biodiversity Scenarios: Projections of 21st Century Change in Biodiversity and Associated Ecosystem Services. 
[20] Salamin, N., Wüest, R.O., Lavergne, S., et al. (2010) Assessing Rapid Evolution in a Changing Environment. Trends in Ecology \& Evolution, 25, 692-698. https://doi.org/10.1016/j.tree.2010.09.009

[21] Pereira, H.M., Leadley, P.W., Proença, V., et al. (2010) Scenarios for Global Biodiversity in the 21st Century. Science, 330, 1496-1501. https://doi.org/10.1126/science.1196624

[22] Kingdon, J. (1997) The Kingdon Field Guide to African Mammals: A\&C Black.

[23] Blanc, J. (2008) Loxodonta africana. The IUCN Red List of Threatened Species.

[24] Du Toit, J.G. (2002) Water Requirements. In: Bothma, J.P., Ed., Game Ranch Management Game Ranch Management, 5th Edition, Van Schaik Publishers, 98-102.

[25] Spinage, C. (1994) Elephants, xvi + 319. T \& AD Poyser Natural History, Norfolk.

[26] Bohrer, G., Beck, P.S., Ngene, S.M., et al. (2014) Elephant Movement Closely Tracks Precipitation-Driven Vegetation Dynamics in a Kenyan Forest-Savanna Landscape. Movement Ecology, 2, 2. https://doi.org/10.1186/2051-3933-2-2

[27] Scheske, L., Ruitenberg, J. and Bissumbhar, B. (2015) Needs and Availability of Snake Antivenoms: Relevance and Application of International Guidelines. International Journal of Health Policy and Management, 4, 447-457. https://doi.org/10.15171/ijhpm.2015.75

[28] Moss, R.H., Edmonds, J., Hibbard, K., et al. (2010) The Next Generation of Scenarios for Climate Change Research and Assessment. Nature, 463, 747-756. https://doi.org/10.1038/nature08823

[29] Altmann, J., Alberts, S.C., Altmann, S.A. and Roy, S.B. (2002) Dramatic Change in Local Climate Patterns in the Amboseli Basin, Kenya. African Journal of Ecology, 40, 248-251. https://doi.org/10.1046/j.1365-2028.2002.00366.x

[30] Norton-Griffiths, M. (1978) Counting Animals. In: Grimsdell, J.J.R., Ed., Handbook No. 1, Serengeti Ecological Monitoring Programme, African Wildlife Leadership Foundation, Nairobi.

[31] Verdin, A., Funk, C. and Rajagopalan, B.K.W. (2016) Kriging and Local Polynomial Methods for Blending Satellite-Derived and Gauge Precipitation Estimates to Support Hydrologic Early Warning Systems. IEEE Transactions on Geoscience and Remote Sensing, 54, 2552-2562.

[32] Funk, C., Peterson, P., Landsfeld, M., et al. (2015) The Climate Hazards Infrared Precipitation with Stations-A New Environmental Record for Monitoring Extremes. Scientific Data, 2, Article ID: 150066. https://doi.org/10.1038/sdata.2015.66

[33] IPCC, Stocker, T.F., Qin, D., et al. (2013) Climate Change 2013-The Physical Science Basis Contribution of Working Group I to the Fifth Assessment Report of the Intergovernmental Panel on Climate Change. Cambridge University Press, Cambridge and New York.

[34] Riahi, K., Rao, S., Krey, V., et al. (2011) RCP 8.5-A Scenario of Comparatively High Greenhouse Gas Emissions. Climatic Change, 109, 33-57. https://doi.org/10.1007/s10584-011-0149-y

[35] Van Vuuren, D.P., Edmonds, J., Kainuma, M., et al. (2011) The Representative Concentration Pathways: An Overview. Climatic Change, 109, 5-31. https://doi.org/10.1007/s10584-011-0148-Z

[36] Nikulin, G., Jones, C., Giorgi, F., et al. (2012) Precipitation Climatology in an Ensemble of CORDEX-Africa Regional Climate Simulations. Journal of Climate, 25, 6057-6078. https://doi.org/10.1175/JCLI-D-11-00375.1 
[37] Endris, H.S. (2016) Projected Changes in Rainfall and Temperature over Greater Horn of Africa (GHA) in Different Scenarios. In Support of: Planning for Resilience in East Africa through Policy, Adaptation, Research, and Economic Development (PREPARED) Project.

[38] Norton-Griffiths, M. (1978) Counting Animals. Africa Wildlife Leadership Foundation, Nairobi.

[39] Burnham, K.P. and Anderson, D.R. (2002) Model Selection and Multimodel Inference: A Practical Information-Theoretic Approach. 2nd Edition.

[40] Ogutu, J.O. (2013) Changing Wildlife Populations in Nairobi National Park and Adjoining Athi-Kaputiei Plains: Collapse of the Migratory Wildebeest. The Open Conservation Biology Journal, 7, 11-26. https://doi.org/10.2174/1874839201307010011

[41] Cushman, S.A., Chase, M. and Griffin, C. (2005) Elephants in Space and Time. Oikos, 109, 331-341. https://doi.org/10.1111/j.0030-1299.2005.13538.x

[42] Woolley, L.-A., Millspaugh, J.J., Woods, R.J., et al. (2009) Intraspecific Strategic Responses of African Elephants to Temporal Variation in Forage Quality. The Journal of Wildlife Management, 73, 827-835. https://doi.org/10.2193/2008-412

[43] Christo, C. and Wilkinson, M. (2009) Walking Thunder. In the Footsteps of the African Elephant.

[44] Garstange, M., Davis, R.E., Leggett, K., et al. (2014) Response of African Elephants (Loxodonta africana) to Seasonal Changes in Rainfall. PLoS ONE, 9, e108736. https://doi.org/10.1371/journal.pone.0108736

[45] Birkett, P.J., Vanak, A.T., Muggeo, V.M.R., et al. (2012) Animal Perception of Seasonal Thresholds: Changes in Elephant Movement in Relation to Rainfall Patterns. PLoS ONE, 7, e38363. https://doi.org/10.1371/journal.pone.0038363

[46] Moss, C.J., Croze, H. and Lee, P.C. (2011) The Amboseli Elephants: A Long-Term Perspective on a Long-Lived Mammal.

[47] Tyrell, J.G. and Coe, M.J. (1974) The Rainfall Regime of Tsavo National Park, Kenya and Its Potential Phenological Significance. Journal of Biogeography, 1, 187-192. https://doi.org/10.2307/3037968

[48] Serneels, S. and Lambin, E.F. (2001) Impact of Land-Use Changes on the Wildebeest Migration in the Northern Part of the Serengeti-Mara Ecosystem. Biogiography, 28, 391-407. https://doi.org/10.1046/j.1365-2699.2001.00557.x

[49] Ogutu, J.O., Owen-smith, N., Piepho, H. and Dublin, H.T. (2015) How Rainfall Variation Influences Reproductive Patterns of African Savanna Ungulates in an Equatorial Region Where Photoperiod Variation Is Absent. 1-13.

[50] Ogutu, J.O., Kuloba, B., Piepho, H. and Kanga, E. (2017) Wildlife Population Dynamics in Human-Dominated Landscapes under Community-Based Conservation: The Example of Nakuru Wildlife Conservancy, Kenya. PLoS ONE, 12, e0169730. https://doi.org/10.1371/journal.pone.0169730

[51] Western, D. (1973) The Structure, Dynamics and Changes of the Amboseli Ecosystem. University of Nairobi, Nairobi.

[52] Inclair, A.R.E., Dublin, H. and Borner, M. (1985) Population Regulation of Serengeti Wildebeest: A Test of the Food Hypothesis. Oecologia, 65, 266-267. https://doi.org/10.1007/BF00379227

[53] Gough, K.F. and Kerley, G.I.H. (2006) Demography and Population Dynamics in the Elephants Loxodonta africana of Addo Elephant National Park, South Africa: Is There Evidence of Density Dependent Regulation? Oryx, 40, 434. 
https://doi.org/10.1017/S0030605306001189

[54] Shiao, L., Wu, Y. and Botkin, D.B. (1980) Of Elephants and Men: A Discrete, Stochastic Model for Long-Lived Species with Complex Life Histories. The American Naturalist, 116, 831-849. https://doi.org/10.1086/283672

[55] De Silva, S., Elizabeth Webber, C., Weerathunga, U.S., et al. (2013) Demographic Variables for Wild Asian Elephants Using Longitudinal Observations. PLOS ONE, 8, e82788.

[56] Davis, M.B. (1986) Climatic Instability, Time Lag, and Community Disequilibrium. In: Diamond, J.M. and Case, T.J., Eds., Community Ecology, Harper and Row, New York, 269-284.

[57] Wittemyer, G., Barner Rasmussen, H. and Douglas-Hamilton, I. (2007) Breeding Phenology in Relation to NDVI Variability in Free-Ranging African Elephant. Ecography, 30, 42-50. https://doi.org/10.1111/j.0906-7590.2007.04900.x

[58] Kioko, M.J.B. (2013) Who Stole the Rain? The Case of Recent Severe Droughts in Kenya.

[59] Stevenson, M.F. and Walter, O. (2006) Management Guidelines for the Welfare of Zoo Animals Elephants Loxodonta africana and Elephas maximus. 2nd Edition, British and Irish Association of Zoos and Aquariums.

[60] NOAA (2017) The First Climate Model. NOAA 200th Celebration.

[61] Phillips, N.A. (1956) The General Circulation of the Atmosphere: A Numerical Experiment. Quarterly Journal of the Royal Meteorological Society, 82, 123-164. https://doi.org/10.1002/qj.49708235202

[62] Giorgi, F. and Ictp, A.S. (2009) Producing a New Generation of Regional Climate Model Projections: The CORDEX Framework.

[63] Rummukainen (2010) State-of-the-Art with Regional Climate Models. Wiley Interdisciplinary Reviews: Climate Change, 1, 82-96.

[64] Luhunga, P., Botai, J. and Kahimba, F. (2016) Evaluation of the Performance of CORDEX Regional Climate Models in Simulating Present Climate Conditions of Tanzania Evaluation of the Performance of CORDEX Regional Climate Models in Simulating Present Climate Conditions of Tanzania. Journal of Southern Hemisphere Earth Systems Science, 66, 32-54.

[65] Chu, P.S., Chen, Y.R. and Schroeder, T.A. (2010) Changes in Precipitation Extremes in the Hawaiian Islands in a Warming Climate. Journal of Climate, 23, 4881-4900. https://doi.org/10.1175/2010JCLI3484.1

[66] Hashemi, H., Uvo, C.B. and Berndtsson, R. (2015) Coupled Modeling Approach to Assess Climate Change Impacts on Groundwater Recharge and Adaptation in Arid Areas. Hydrology and Earth System Sciences, 19, 4165-4181. https://doi.org/10.5194/hess-19-4165-2015

[67] Jenkins, P., Earle-Richardson, G., Burdick, P. and May, J. (2008) Handling Nonresponse in Surveys: Analytic Corrections Compared with Converting Nonresponders. American Journal of Epidemiology, 167, 369-374. https://doi.org/10.1093/aje/kwm297

[68] Teutschbein, C., Wetterhall, F. and Seibert, J. (2011) Evaluation of Different Downscaling Techniques for Hydrological Climate-Change Impact Studies at the Catchment Scale. Climate Dynamics, 37, 2087-2105. https://doi.org/10.1007/s00382-010-0979-8

[69] Wilby, R.L., Charles, S.P., Zorita, E., et al. (2004) Guidelines for Use of Climate Scenarios Developed from Statistical Downscaling Methods. Analysis, 27, 1-27. 
[70] Sillmann, J., Kharin, V.V., Zwiers, F.W., et al. (2013) Climate Extremes Indices in the CMIP5 Multimodel Ensemble: Part 2. Future Climate Projections. Journal of Geophysical Research: Atmospheres, 118, 2473-2493. https://doi.org/10.1002/jgrd.50188

[71] Laprise, R., Hernández-Díaz, L., Tete, K., et al. (2013) Climate Projections over CORDEX Africa Domain Using the Fifth-Generation Canadian Regional Climate Model (CRCM5). Climate Dynamics, 41, 3219-3246. https://doi.org/10.1007/s00382-012-1651-2

[72] World Bank (2013) Turn Down Heat. The Climate Extremes, Regional Impacts, and the Case for Resilience. Washington DC.

[73] Alexander, L.V., Zhang, X., Peterson, T.C., et al. (2006) Global Observed Changes in Daily Climate Extremes of Temperature and Precipitation. Journal of Geophysical Research: Atmospheres, 111, 1-22. https://doi.org/10.1029/2005JD006290

[74] Tebaldi, C., Hayhoe, K., Arblaster, J.M. and Meehl, G.A. (2006) Going to the Extremes: An Intercomparison of Model-Simulated Historical and Future Changes in Extreme Events. Climatic Change, 79, 185-211. https://doi.org/10.1007/s10584-006-9051-4

[75] Kharin, V.V., Zwiers, F.W., Zhang, X. and Hegerl, G.C. (2007) Changes in Temperature and Precipitation Extremes in the IPCC Ensemble of Global Coupled Model Simulations. Journal of Climate, 20, 1419-1444. https://doi.org/10.1175/JCLI4066.1

[76] Kharin, V.V., Zwiers, F.W., Zhang, X. and Wehner, M. (2013) Changes in Temperature and Precipitation Extremes in the CMIP5 Ensemble. Climatic Change, 119, 345-357. https://doi.org/10.1007/s10584-013-0705-8

[77] Wang, G., Wang, D., Trenberth, K.E., et al. (2017) The Peak Structure and Future Changes of the Relationships between Extreme Precipitation and Temperature. $\mathrm{Na}$ ture Climate Change, 7, 268-274. https://doi.org/10.1038/nclimate3239

[78] Ndiritu, M.J. (2013) Mathematical and Statistical Population Models: Elephants Population Modeling. 171.

[79] Poole, J.H. (1989) Mate Guarding, Reproductive Success and Female Choice in African Elephants. Animal Behaviour, 37, 842-849. https://doi.org/10.1016/0003-3472(89)90068-7

[80] Rubenstein, D.I. (1992) The Greenhouse Effect and Changes in Animal Behavior: Effects on Social Structure and Life-History Strategies. In: Lovejoy, R.L.P., Ed., Global Warming and Biological Diversity, Yale University Press, New Haven, 180-192.

[81] Moss, C.J. (2001) The Demography of an African Elephant (Loxodonta africana) Population in Amboseli, Kenya. Journal of Zoology, 255, 145-156. https://doi.org/10.1017/S0952836901001212

[82] Leggett, K.E.A. (2006) Home Range and Seasonal Movement of Elephants in the Kunene Region, Northwestern Namibia. African Zoology, 41, 17-36. https://doi.org/10.1080/15627020.2006.11407332

[83] Foley, C., Pettorelli, N. and Foley, L. (2008) Severe Drought and Calf Survival in Elephants. Population Ecology, 4, 541-544.

[84] Lee, P.C., Bussière, L.F., Webber, C.E., et al. (2013) Enduring Consequences of Early Experiences: 40 Year Effects on Survival and Success among African Elephants (Loxodonta africana). Biology Letters, 9, Article ID: 20130011. https://doi.org/10.1098/rsbl.2013.0011

[85] Owen-Smith, N. (2006) Demographic Determination of the Shape of Density De- 
pendence for Three African Ungulate Populations. Ecological Monographs, 76, 93-109. https://doi.org/10.1890/05-0765

[86] Corfield, T.F. (1973) Elephant Mortality in Tsavo National Park, Kenya. African Journal of Ecology, 11, 339-368. https://doi.org/10.1111/j.1365-2028.1973.tb00098.x

[87] Mumby, H.S., Courtiol, A., Mar, K.U. and Lummaa, V. (2013) Birth Seasonality and Calf Mortality in a Large Population of Asian Elephants. Ecology and Evolution, 3, 3794-3803. https://doi.org/10.1002/ece3.746

[88] Ogutu, J.O., Piepho, H.-P., Said, M.Y. and Kifugo, S.C. (2014) Herbivore Dynamics and Range Contraction in Kajiado County Kenya: Climate and Land Use Changes, Population Pressures, Governance, Policy and Human-wildlife Conflicts. The Open Ecology Journal, 7, 9-31. https://doi.org/10.2174/1874213001407010009

[89] Pricope, N.G., Husak, G., Lopez-Carr, D., et al. (2013) The Climate-Population Nexus in the East African Horn: Emerging Degradation Trends in Rangeland and Pastoral Livelihood Zones. Global Environmental Change, 23, 1525-1541. https://doi.org/10.1016/j.gloenvcha.2013.10.002

[90] CBS (1981) Kenya Population Census 1979. Volume 1. Central Bureau of Statistics (CBS). Ministry of Economic Planning and Development, Nairobi.

[91] KNBS (2010) The 2009 Kenya Population and Housing Census. Counting Our People for the Implementation of Vision 2030. Volume II. Kenya National Bureau of Statistics, Ministry of State for Planning, National Development and Vision 2030, Nairobi.

[92] Okello, M.M., Njumbi, S.J., Kiringe, J.W. and Isiiche, J. (2014) Prevalence and Severity of Current Human-Elephant Conflicts in Amboseli Ecosystem, Kenya: Insights from the Field and Key Informants. Natural Resources, 5, 462-477. https://doi.org/10.4236/nr.2014.59043

[93] IUCN (2013) IUCN Annual Report.

[94] Said, M.Y., Ogutu, J.O., Kifugo, S.C., et al. (2016) Effects of Extreme Land Fragmentation on Wildlife and Livestock Population Abundance and Distribution. Journal for Nature Conservation, 34, 151-164. https://doi.org/10.1016/j.jnc.2016.10.005

[95] Ojwang, G.O., Wargute, P.W., Said, M.Y., et al. (2017) Wildlife Migratory Corridors and Dispersal Areas: Kenya Rangelands and Coastal Terrestrial Ecosystems.

[96] Wayumba, R. and Mwenda, J.N. (2006) The Impact of Changing Land Tenure and Land Use on Wildlife Migration within Group Ranches in Kenya: A Case Study of the Amboseli Ecosystem.

[97] Western, D., Groom, R. and Worden, J. (2009) The Impact of Subdivision and Sedentarization of Pastoral Lands on Wildlife in an African Savanna Ecosystem. Biological Conservation, 142, 2538-2546. https://doi.org/10.1016/j.biocon.2009.05.025

[98] Georgiadis, N.J., Olwero, N., Ojwang, G. and Aike, G. (2010) Reassessing Aerial Sample Surveys for Wildlife Monitoring, Conservation, and Management. Smithsonian Contributions to Zoology, 632, 31-42.

[99] Groom, R.J. and Western, D. (2013) Impact of Land Subdivision and Sedentarization on Wildlife in Kenya's Southern Rangelands. Rangeland Ecology \& Management, 66, 1-9. https://doi.org/10.2111/REM-D-11-00021.1

[100] Kitina Nyamasyo, S. and Odiara Kihima, B. (2014) Changing Land Use Patterns and Their Impacts on Wild Ungulates in Kimana Wetland Ecosystem, Kenya. International Journal of Biodiversity, 2014, Article ID: 486727.

[101] Mwenda, J. (2001) Spatial Information in Land Tenure Reform with Special Refer- 
ence to Kenya.

[102] Reimer, J.R., Bonsall, M.B. and Maini, P.K. (2016) The Critical Domain Size of Stochastic Population Models. Journal of Mathematical Biology, 74, 1-28.

[103] Wood, K.A., Stillman, R.A., Daunt, F. and O'Hare, M.T. (2013) Evaluating the Effects of Population Management on a Herbivore Grazing Conflict. PLoS ONE, 8, e56287. https://doi.org/10.1371/journal.pone.0056287 


\section{Supplementary Material}

Table S1. Rainfall trend for Amboseli Ecosystem for period 1960-2014.

\begin{tabular}{cccc}
\hline Month & Equation & F-Ratio & P-Value \\
\hline January & $\mathrm{Y}=337.476-0.148 \mathrm{x}$ & 0.120 & 0.729 \\
February & $\mathrm{Y}=329.801-0.151 \mathrm{x}$ & 0.312 & 0.578 \\
March & $\mathrm{Y}=-200.929+0.145 \mathrm{x}$ & 0.077 & 0.782 \\
April & $\mathrm{Y}=853.925-0.381 \mathrm{x}$ & 0.481 & 0.491 \\
May & $\mathrm{Y}=787.946-0.374 \mathrm{x}$ & 1.676 & 0.201 \\
June & $\mathrm{Y}=244.554-0.121 \mathrm{x}$ & 3.979 & 0.051 \\
July & $\mathrm{Y}=254.688-0.127 \mathrm{x}$ & 5.672 & 0.021 \\
August & $\mathrm{Y}=-6.734+0.006 \mathrm{x}$ & 0.012 & 0.914 \\
September & $\mathrm{Y}=211.626-0.104 \mathrm{x}$ & 1.573 & 0.215 \\
October & $\mathrm{Y}=538.203-0.254 \mathrm{x}$ & 0.709 & 0.403 \\
November & $\mathrm{Y}=1399.651-0.646 \mathrm{x}$ & 1.156 & 0.287 \\
December & $\mathrm{Y}=-123.509+0.119 \mathrm{x}$ & 0.066 & 0.798
\end{tabular}

Table S2. (a) Rainfall trend for Amboseli Ecosystem for RCP 2.6 for period 2006 to 2100; (b) Rainfall trend for Amboseli Ecosystem for RCP 4.5for period 2006 to 2100; (c) Rainfall trend for Amboseli Ecosystem for RCP 8.5for period 2006 to 2100.

(a)

\begin{tabular}{cccc}
\hline Month & Equation & F-Ratio & P-Value \\
\hline January & $\mathrm{Y}=-142.717+0.082 \mathrm{x}$ & 0.602 & 0.440 \\
February & $\mathrm{Y}=-20.183+0.025 \mathrm{x}$ & 0.046 & 0.831 \\
March & $\mathrm{Y}=54.053+0.001 \mathrm{x}$ & 0.000 & 0.997 \\
April & $\mathrm{Y}=-211.375+0.157 \mathrm{x}$ & 0.506 & 0.478 \\
May & $\mathrm{Y}=504.036-0.220 \mathrm{x}$ & 2.546 & 0.114 \\
June & $\mathrm{Y}=11.645-0.001 \mathrm{x}$ & 0.001 & 0.982 \\
July & $\mathrm{Y}=10.758-0.004 \mathrm{x}$ & 0.049 & 0.826 \\
August & $\mathrm{Y}=5.334+0.000 \mathrm{x}$ & 0.000 & 0.985 \\
September & $\mathrm{Y}=66.299-0.025 \mathrm{x}$ & 0.273 & 0.602 \\
October & $\mathrm{Y}=-131.986+0.107 \mathrm{x}$ & 0.422 & 0.517 \\
November & $\mathrm{Y}=1098.179-0.451 \mathrm{x}$ & 3.382 & 0.069 \\
December & $\mathrm{Y}=-480.955+0.264 \mathrm{x}$ & 2.851 & 0.095 \\
\hline
\end{tabular}

(b)

\begin{tabular}{cccc}
\hline Month & Equation & F-Ratio & P-Value \\
\hline January & $\mathrm{Y}=-22.115+0.026 \mathrm{x}$ & 0.053 & 0.819 \\
February & $\mathrm{Y}=-14.593+0.006 \mathrm{x}$ & 0.004 & 0.952 \\
March & $\mathrm{Y}=-86.153+0.069 \mathrm{x}$ & 0.210 & 0.648 \\
April & $\mathrm{Y}=133.989+0.004 \mathrm{x}$ & 0.000 & 0.989 \\
May & $\mathrm{Y}=417.550-0.172 \mathrm{x}$ & 1.430 & 0.235 \\
June & $\mathrm{Y}=46.587-0.019 \mathrm{x}$ & 0.393 & 0.532 \\
July & $\mathrm{Y}=3.364-0.001 \mathrm{x}$ & 0.000 & 0.983 \\
August & $\mathrm{Y}=5.594-0.001 \mathrm{x}$ & 0.001 & 0.978 \\
September & $\mathrm{Y}=25.706-0.005 \mathrm{x}$ & 0.007 & 0.933 \\
October & $\mathrm{Y}=35.804+0.030 \mathrm{x}$ & 0.028 & 0.867 \\
November & $\mathrm{Y}=-235.315+0.202 \mathrm{x}$ & 0.577 & 0.450 \\
December & $\mathrm{Y}=-51.530+0.056 \mathrm{x}$ & 0.187 & 0.667 \\
\hline
\end{tabular}


(c)

\begin{tabular}{cccc}
\hline Month & Equation & F-Ratio & P-Value \\
\hline January & $\mathrm{Y}=-560.252+0.288 \mathrm{x}$ & 6.674 & 0.011 \\
February & $\mathrm{Y}=-474.387+0.246 \mathrm{x}$ & 4.650 & 0.034 \\
March & $\mathrm{Y}=-787.628+0.413 \mathrm{x}$ & 5.883 & 0.017 \\
April & $\mathrm{Y}=141.288-0.003 \mathrm{x}$ & 0.000 & 0.900 \\
May & $\mathrm{Y}=301.708-0.117 \mathrm{x}$ & 0.570 & 0.452 \\
June & $\mathrm{Y}=14.681-0.003 \mathrm{x}$ & 0.007 & 0.935 \\
July & $\mathrm{Y}=30.474-0.014 \mathrm{x}$ & 0.746 & 0.390 \\
August & $\mathrm{Y}=74.154-0.034 \mathrm{x}$ & 2.705 & 0.103 \\
September & $\mathrm{Y}=271-425-0.126 \mathrm{x}$ & 8.538 & 0.004 \\
October & $\mathrm{Y}=-402.387+0.239 \mathrm{x}$ & 1.653 & 0.202 \\
November & $\mathrm{Y}=-1461.509+0.810 \mathrm{x}$ & 8.719 & 0.004 \\
December & $\mathrm{Y}=-1154.100+0.602 \mathrm{x}$ & 10.94 & 0.001 \\
\hline
\end{tabular}

Table S3. Relationship between elephant population and maximum temperature in the Amboseli Ecosystem.

\begin{tabular}{cccc}
\hline Temperature & Equation & F-Ratio & P-Value \\
\hline Month $_{1}$ & $\mathrm{Y}=-2121.957+103.151 \mathrm{x}$ & 1.018 & 0.333 \\
Month $_{2}$ & $\mathrm{Y}=-2110.941+102.035 \mathrm{x}$ & 0.889 & 0.364 \\
Month $_{3}$ & $\mathrm{Y}=-2855.950+127.978 \mathrm{x}$ & 1.855 & 0.198 \\
Month $_{4}$ & $\mathrm{Y}=-1946.839+98.369 \mathrm{x}$ & 1.067 & 0.322 \\
Month $_{5}$ & $\mathrm{Y}=-1743.923+92.378 \mathrm{x}$ & 0.831 & 0.374 \\
Month $_{6}$ & $\mathrm{Y}=-1232.805+74.864 \mathrm{x}$ & 0.465 & 0.508 \\
Month $_{7}$ & $\mathrm{Y}=-1253.273+75.607 \mathrm{x}$ & 0.341 & 0.569 \\
Month $_{8}$ & $\mathrm{Y}=-1743.729+92.873 \mathrm{x}$ & 0.283 & 0.604 \\
Month $_{9}$ & $\mathrm{Y}=-3852.064+166.924 \mathrm{x}$ & 0.469 & 0.506 \\
Month $_{10}$ & $\mathrm{Y}=-7301.423+288.319 \mathrm{x}$ & 1.038 & 0.328 \\
Month $_{11}$ & $\mathrm{Y}=-8802.127+341.049 \mathrm{x}$ & 1.379 & 0.262 \\
Month $_{12}$ & $\mathrm{Y}=-7837.906+306.831 \mathrm{x}$ & 1.125 & 0.309
\end{tabular}

